\title{
Geology and Assessment of Undiscovered Oil and Gas Resources of the Arctic Alaska Province, 2008
}

Chapter E of

The 2008 Circum-Arctic Resource Appraisal

Professional Paper 1824

Supersedes USGS Scientific Investigations Report 2012-5147

U.S. Department of the Interior

U.S. Geological Survey 
Cover. Northwestward view across the southern foothills of the Brooks Range along Akmagolik Creek, approximately 150 miles southwest of Prudhoe Bay. Exposed rocks are part of the MississippianPennsylvanian Lisburne Group and include a thrust-fault ramp at left. This area is included in the Arctic Alaska Fold-and-Thrust Belt Assessment Unit discussed in text. Photo includes two helicopters for scale, a blue-and-white one near the center and a red one at center-right at creek level. 


\section{Geology and Assessment of Undiscovered Oil and Gas Resources of the Arctic Alaska Province, 2008}

By David W. Houseknecht, Kenneth J. Bird, and Christopher P. Garrity

Chapter E of

The $\mathbf{2 0 0 8}$ Circum-Arctic Resource Appraisal

Edited by T.E. Moore and D.L. Gautier

Professional Paper 1824

Supersedes USGS Scientific Investigations Report 2012-5147 


\title{
U.S. Department of the Interior \\ DAVID BERNHARDT, Secretary
}

\section{U.S. Geological Survey James F. Reilly II, Director}

\author{
U.S. Geological Survey, Reston, Virginia: 2019 \\ Supersedes USGS Scientific Investigations Report 2012-5147
}

For more information on the USGS - the Federal source for science about the Earth, its natural and living resources, natural hazards, and the environment-visit https://www.usgs.gov or call 1-888-ASK-USGS.

For an overview of USGS information products, including maps, imagery, and publications,

visit https://store.usgs.gov.

Any use of trade, firm, or product names is for descriptive purposes only and does not imply endorsement by the U.S. Government.

Although this information product, for the most part, is in the public domain, it also may contain copyrighted materials as noted in the text. Permission to reproduce copyrighted items must be secured from the copyright owner.

Suggested citation:

Houseknecht, D.W., Bird, K.J., and Garrity, C.P., 2019, Geology and assessment of undiscovered oil and gas resources of the Arctic Alaska Province, 2008, chap. E of Moore, T.E., and Gautier, D.L., eds., The 2008 Circum-Arctic Resource Appraisal: U.S. Geological Survey Professional Paper 1824, 25 p., https://doi.org/10.3133/pp1824E. [Supersedes USGS Scientific Investigations Report 2012-5147.]

ISSN 2330-7102 (online) 


\section{The 2008 Circum-Arctic Resource Appraisal}

\section{Chapters}

A. Introduction to the 2008 Circum-Arctic Resource Appraisal (CARA) Professional Paper By Donald L. Gautier and Thomas E. Moore

B. Methodology for Assessment of Undiscovered Oil and Gas Resources for the 2008 Circum-Arctic Resource Appraisal

By Ronald R. Charpentier

\section{North America}

C. Geology and Assessment of Undiscovered Oil and Gas Resources of the Chukchi Borderland Province, 2008

By Kenneth J. Bird and David W. Houseknecht

D. Geology and Assessment of Undiscovered Oil and Gas Resources of the Hope Basin

Province, 2008

By Kenneth J. Bird, David W. Houseknecht, and Janet K. Pitman

E. Geology and Assessment of Undiscovered Oil and Gas Resources of the Arctic Alaska Province, 2008

By David W. Houseknecht, Kenneth J. Bird, and Christopher P. Garrity

F. Geology and Assessment of Undiscovered Oil and Gas Resources of the Yukon Flats Basin Province, 2008

By Kenneth J. Bird and Richard G. Stanley

G. Geology and Assessment of Undiscovered Oil and Gas Resources of the Northwest Canada Interior Basins Province, Arctic Canada, 2008

By Marilyn E. Tennyson and Janet K. Pitman

H. Geology and Assessment of Undiscovered Oil and Gas Resources of the Franklinian Shelf Province, Arctic Canada and North Greenland, 2008

By Marilyn E. Tennyson and Janet K. Pitman

I. Geology and Assessment of Undiscovered Oil and Gas Resources of the Sverdrup Basin Province, Arctic Canada, 2008

By Marilyn E. Tennyson and Janet K. Pitman 


\section{Greenland}

J. Geology and Assessment of Undiscovered Oil and Gas Resources of the West GreenlandEast Canada Province, 2008

By Christopher J. Schenk

K. Geology and Assessment of Undiscovered Oil and Gas Resources of the East Greenland Rift Basins Province, 2008

By Donald L. Gautier

\section{North Atlantic Ocean}

L. Geology and Assessment of Undiscovered Oil and Gas Resources of the Jan Mayen Microcontinent Province, 2008

By Thomas E. Moore and Janet K. Pitman

\section{Eurasia}

M. Geology and Assessment of Undiscovered Oil and Gas Resources of the Mezen' Basin Province, 2008

By Timothy R. Klett and Janet K. Pitman

N. Geology and Assessment of Undiscovered Oil and Gas Resources of the Timan-Pechora Basin Province, Russia, 2008

By Christopher J. Schenk

0. Geology and Assessment of Undiscovered Oil and Gas Resources of the East Barents Basins Province and the Novaya Zemlya Basins and Admiralty Arch Province, 2008

By Timothy R. Klett

P. Geology and Assessment of Undiscovered Oil and Gas Resources of the North Kara Basins and Platforms Province, 2008

By Timothy R. Klett and Janet K. Pitman

0. Geology and Assessment of Undiscovered Oil and Gas Resources of the Northern West Siberian Mesozoic Composite Total Petroleum System of the West Siberian Basin Province, Russia, 2008

By Christopher J. Schenk

R. Geology and Assessment of Undiscovered Oil and Gas Resources of the Yenisey-Khatanga Basin Province, 2008

By Timothy R. Klett and Janet K. Pitman

S. Geology and Assessment of Undiscovered Oil and Gas Resources of the Northwest Laptev Sea Shelf Province, 2008

By Timothy R. Klett and Janet K. Pitman 
T. Geology and Assessment of Undiscovered Oil and Gas Resources of the Lena-Anabar Basin Province, 2008

By Timothy R. Klett and Janet K. Pitman

U. Geology and Assessment of Undiscovered Oil and Gas Resources of the Tunguska Basin Province, 2008

By Craig J. Wandrey and Timothy R. Klett

V. Geology and Assessment of Undiscovered Oil and Gas Resources of the Lena-Vilyui Basin Province, 2008

By Timothy R. Klett and Janet K. Pitman

W. Geology and Assessment of Undiscovered Oil and Gas Resources of the Laptev Sea Shelf Province, 2008

By Timothy R. Klett and Janet K. Pitman

X. Geology and Assessment of Undiscovered Oil and Gas Resources of the Zyryanka Basin Province, 2008

By Timothy R. Klett and Janet K. Pitman

Y. Geology and Assessment of Undiscovered Oil and Gas Resources of the East Siberian Sea Basin Province, 2008

By Kenneth J. Bird, David W. Houseknecht, and Janet K. Pitman

Z. Geology and Assessment of Undiscovered Oil and Gas Resources of the Vilkitskii Basin

Province, 2008

By Kenneth J. Bird, David W. Houseknecht, and Janet K. Pitman

AA. Geology and Assessment of Undiscovered Oil and Gas Resources of the Long Strait Province, 2008

By Kenneth J. Bird, David W. Houseknecht, and Janet K. Pitman

\section{Arctic Ocean}

BB. Geology and Assessment of Undiscovered Oil and Gas Resources of the Amerasia Basin Province, 2008

By David W. Houseknecht, Kenneth J. Bird, and Christopher P. Garrity

CC. Geology and Assessment of Undiscovered Oil and Gas Resources of the LomonosovMakarov Province, 2008

By Thomas E. Moore, Kenneth J. Bird, and Janet K. Pitman

DD. Geology and Assessment of Undiscovered Oil and Gas Resources of the Eurasia Basin Province, 2008

By Thomas E. Moore and Janet K. Pitman 


\section{Contents}

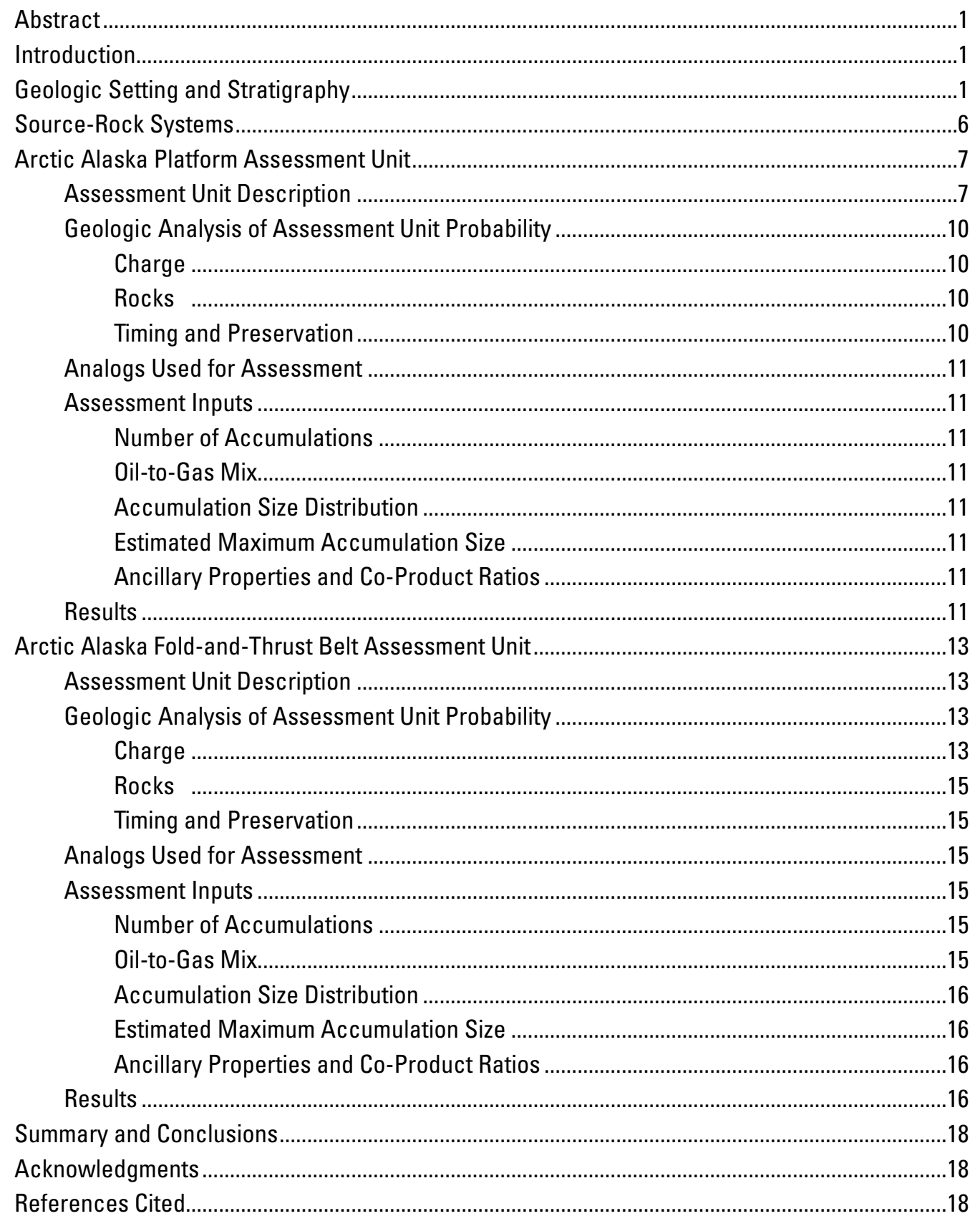




\section{Figures}

1. Map of Arctic Alaska Province (outlined in black) showing boundaries of the platform and fold-and-thrust belt assessment units in red

2. Generalized cross section showing stratigraphic and structural relations from the Brooks Range to the northern margin of the Alaska rift shoulder, central North Slope of Alaska.

3. Generalized chronostratigraphy for the Arctic Alaska Province, based on the geology of the Alaska North Slope

4. Maps showing the three main oil-prone source-rock systems in the Arctic Alaska Province. 4

5. Map of thermal maturity at the base of the Brookian sequence across the Arctic Alaska Province and the southern Canada Basin.

6. Petroleum systems plots for two wells in the Arctic Alaska Province...

7. Map of Arctic Alaska Platform Assessment Unit showing locations of exploration wells and known accumulations of oil and gas

8. Map of Arctic Alaska Fold-and-Thrust Belt Assessment Unit showing locations of exploration wells and known accumulations of oil and gas

\section{Tables}

1. Analog assessment units used to constrain input parameters for the Arctic Alaska Platform Assessment Unit.

2. Analog assessment units used to constrain input parameters for the Arctic Alaska Fold-and-Thrust Belt Assessment Unit

3. Summary of results for risked, undiscovered, technically recoverable petroleum resources for the Arctic Alaska Province.

\section{Appendixes}

[Available for download at https://doi.org/10.3133/pp1824E]

1. Input data for the Arctic Alaska Platform Assessment Unit

2. Input data for the Arctic Alaska Fold-and-Thrust Belt Assessment Unit 


\section{Conversion Factors}

\begin{tabular}{lcc}
\hline \multicolumn{1}{c}{ Multiply } & By & To obtain \\
\hline meter $(\mathrm{m})$ & \multicolumn{1}{c}{ Length } & \\
meter $(\mathrm{m})$ & 3.281 & foot $(\mathrm{ft})$ \\
kilometer $(\mathrm{km})$ & 1.094 & yard $(\mathrm{yd})$ \\
kilometer $(\mathrm{km})$ & 0.6214 & mile (mi) \\
& 0.5400 & mile, nautical (nmi) \\
\hline square kilometer $\left(\mathrm{km}^{2}\right)$ & 247.1 & Area \\
square kilometer $\left(\mathrm{km}^{2}\right)$ & 0.3861 & square mile $\left(\mathrm{mi}^{2}\right)$ \\
\hline & \multicolumn{1}{c}{ Volume } & \\
\hline barrel $(\mathrm{bbl}),(\mathrm{petroleum}$, & 0.1590 & cubic meter $\left(\mathrm{m}^{3}\right)$ \\
1 barrel=42 gal) & 28.32 & cubic decimeter $\left(\mathrm{dm}^{3}\right)$ \\
cubic foot $\left(\mathrm{ft}^{3}\right)$ & 0.02832 & cubic meter $\left(\mathrm{m}^{3}\right)$ \\
cubic foot $\left(\mathrm{ft}^{3}\right)$ & & \\
\hline
\end{tabular}




\title{
Geology and Assessment of Undiscovered Oil and Gas Resources of the Arctic Alaska Province, 2008
}

\author{
By David W. Houseknecht, Kenneth J. Bird, and Christopher P. Garrity
}

\begin{abstract}
The Arctic Alaska Province encompasses all lands and adjacent continental shelf areas north of the Brooks RangeHerald Arch tectonic belts and south of the northern (outboard) margin of the Alaska rift shoulder. Even though only a small part is thoroughly explored, it is one of the most prolific petroleum provinces in North America, with total known resources (cumulative production plus proved reserves) of about 28 billion barrels of oil equivalent.

For assessment purposes, the province is divided into a platform assessment unit, comprising the Alaska rift shoulder and its relatively undeformed flanks, and a fold-and-thrust belt assessment unit, comprising the deformed area north of the Brooks Range and Herald Arch tectonic belts. Mean estimates of undiscovered, technically recoverable resources include nearly 28 billion barrels of oil and 122 trillion cubic feet of nonassociated gas in the platform assessment unit and 2 billion barrels of oil and 59 trillion cubic feet of nonassociated gas in the fold-and-thrust belt assessment unit.
\end{abstract}

\section{Introduction}

The U.S. Geological Survey (USGS) in 2008 completed an appraisal of undiscovered, technically recoverable, conventional oil and gas resources north of the Arctic Circle. Results of that Circum-Arctic Resource Appraisal (CARA) include aggregate resource estimates for the entire Arctic region (Bird and others, 2008; Gautier and others, 2009, 2011a) and documentation of the geologic framework and resource estimates for specific Arctic provinces (Bird and Houseknecht, 2011; Gautier and others, 2011b; Houseknecht and Bird, 2011; Klett and Pitman, 2011; Klett and others, 2011; Moore and Pitman, 2011; Moore and others, 2011; Schenk, 2011a, b; Sørensen and others, 2011). In addition, the procedures and methods used in conducting the Circum-Arctic Resource Appraisal have been documented by Charpentier and Gautier (2011) and Charpentier (2017 [this volume]). The purpose of this report is to provide a synthesis of the geology of the Arctic Alaska Province and to present input parameters and results of the resource assessment.

The Arctic Alaska Province extends from the northern margin of the Brooks Range and Herald Arch tectonic belts on the south and southwest to the northern margin of the Alaska rift shoulder (Houseknecht and Bird, 2011) on the north, and from the axis of the Chukchi platform on the northwest to the western margin of the Mackenzie River delta on the east (fig. 1). The province is about $1,400 \mathrm{~km}$ long (west-east) and ranges in width (south-north) from about $500 \mathrm{~km}$ in the west to about $50 \mathrm{~km}$ in the east. The province includes the Alaska North Slope, the Alaska and Canada Brooks Range foothills, part of the Alaska and Canada Beaufort shelf, and most of the U.S. Chukchi shelf. The province is divided into two assessment units, the Arctic Alaska Platform Assessment Unit and the Actic Alaska Fold-and-Thurst Belt Assessment Unit.

\section{Geologic Setting and Stratigraphy}

The most notable geologic features of the province are the Alaska rift shoulder, the Colville foreland basin, and the Brooks Range and Herald Arch fold-thrust belts (figs. 1, 2). The Alaska rift shoulder formed during the Jurassic-Early Cretaceous opening of the Canada Basin (Grantz and May, 1982; Lawver and Scotese, 1990; Grantz and others, 1990, 2011; Embry, 1990, 2000; Lane, 1997; Lawver and others, 2002, 2011; Houseknecht and Bird, 2011). The Arctic Alaska microplate (including Arctic Alaska and the Chukchi shelf) rifted from Arctic Canada, perhaps by counterclockwise rotational opening of the Canada Basin or alternative motions. The rift shoulder is defined by high-standing acoustic basement, whose upper surface generally dips southward beneath Arctic Alaska and the Chukchi shelf and steps northward over a short distance across normal faults to great depths beneath the Beaufort shelf (fig. 2). This abrupt northern boundary of the rift shoulder defines the Alaska (Beaufort) hinge (fig. 2). The current structural crest of the rift shoulder is commonly 


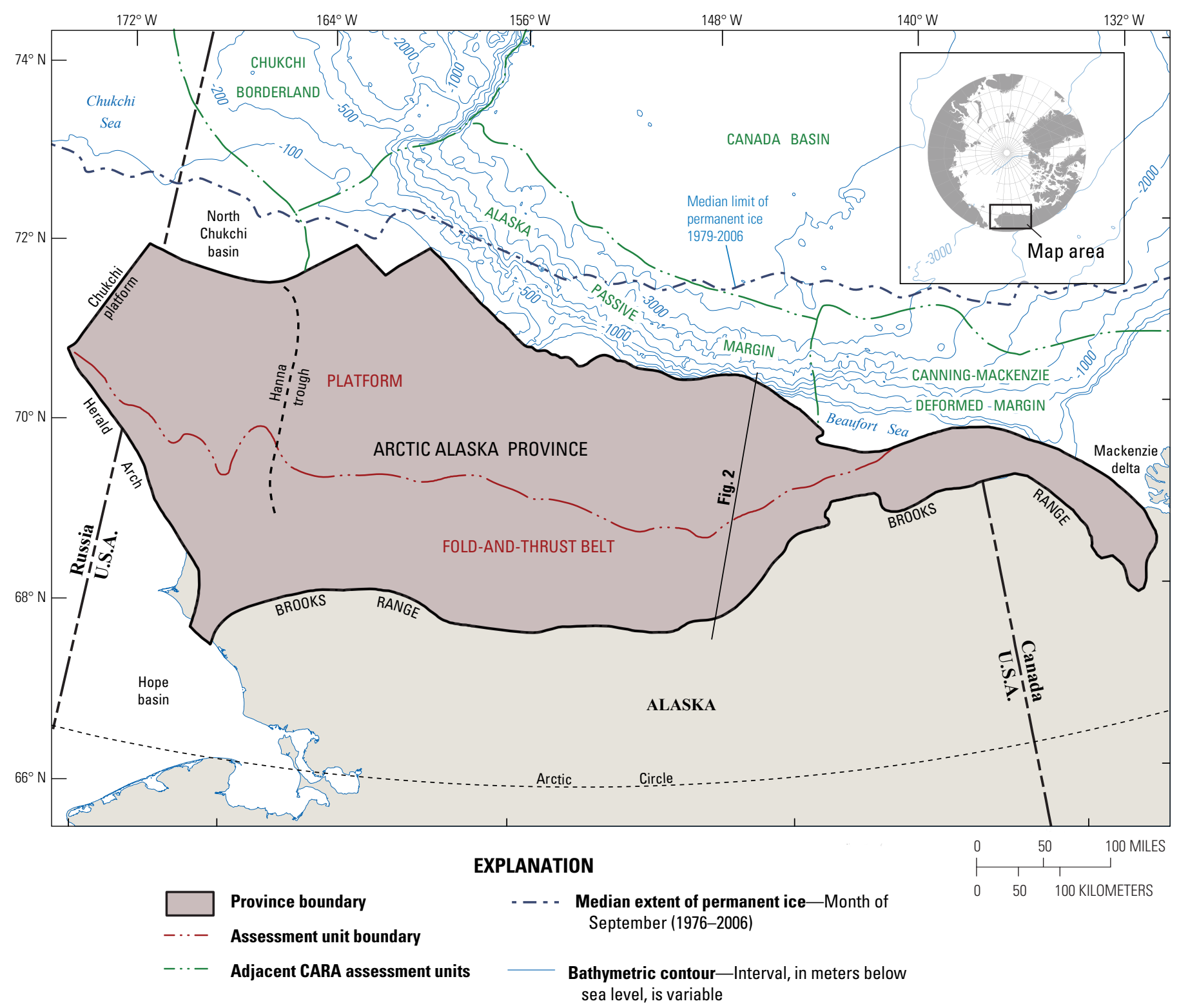

Figure 1. Map of Arctic Alaska Province (outlined in black) showing boundaries of the platform and fold-and-thrust belt assessment units in red. Location of cross section in fig. 2 is shown by thin black line. Blue lines, bathymetry in meters; green lines, boundaries of adjacent Circum-Arctic Resource Appraisal (CARA) assessment units.

known as the Barrow Arch (fig. 2) and is tens of kilometers south of the hinge. This structural geometry is the result of several geologic processes, including thermal contraction and sedimentary loading of the northern margin of the rift shoulder, sediment loading of the southern flank of the rift shoulder by Colville basin strata, and perhaps flexural uplift of the Barrow Arch by tectonic loading of the Arctic Alaska microplate by the Brooks Range. Acoustic basement of the Arctic Alaska microplate is thought to consist mostly of pre-Mississippian low-rank metamorphic rocks known as the Franklinian sequence (fig. 3), which was broadly deformed during the Ellesmerian orogeny (Late Devonian-Early Mississippian; Balkwill and others, 1983; Moore and others, 1994;
Dumoulin, 2001), although aeromagnetic and gravity data suggest a much more heterogeneous basement (see, for example, Saltus and others, 2006).

Franklinian basement in Arctic Alaska is overlain by Mississippian-Cretaceous strata (fig. 3) deposited before (Ellesmerian sequence) and during (Beaufortian sequence) rift opening of the Canada Basin. The older part of the Ellesmerian sequence, which in places may be as old as Devonian, locally includes thick graben-filling successions, and the younger part comprises passive-margin deposits (Bird, 2001; Sherwood and others, 2002; Bird and Houseknecht, 2011). The Beaufortian sequence and, in many areas, the Ellesmerian sequence are truncated progressively northward beneath the Lower 


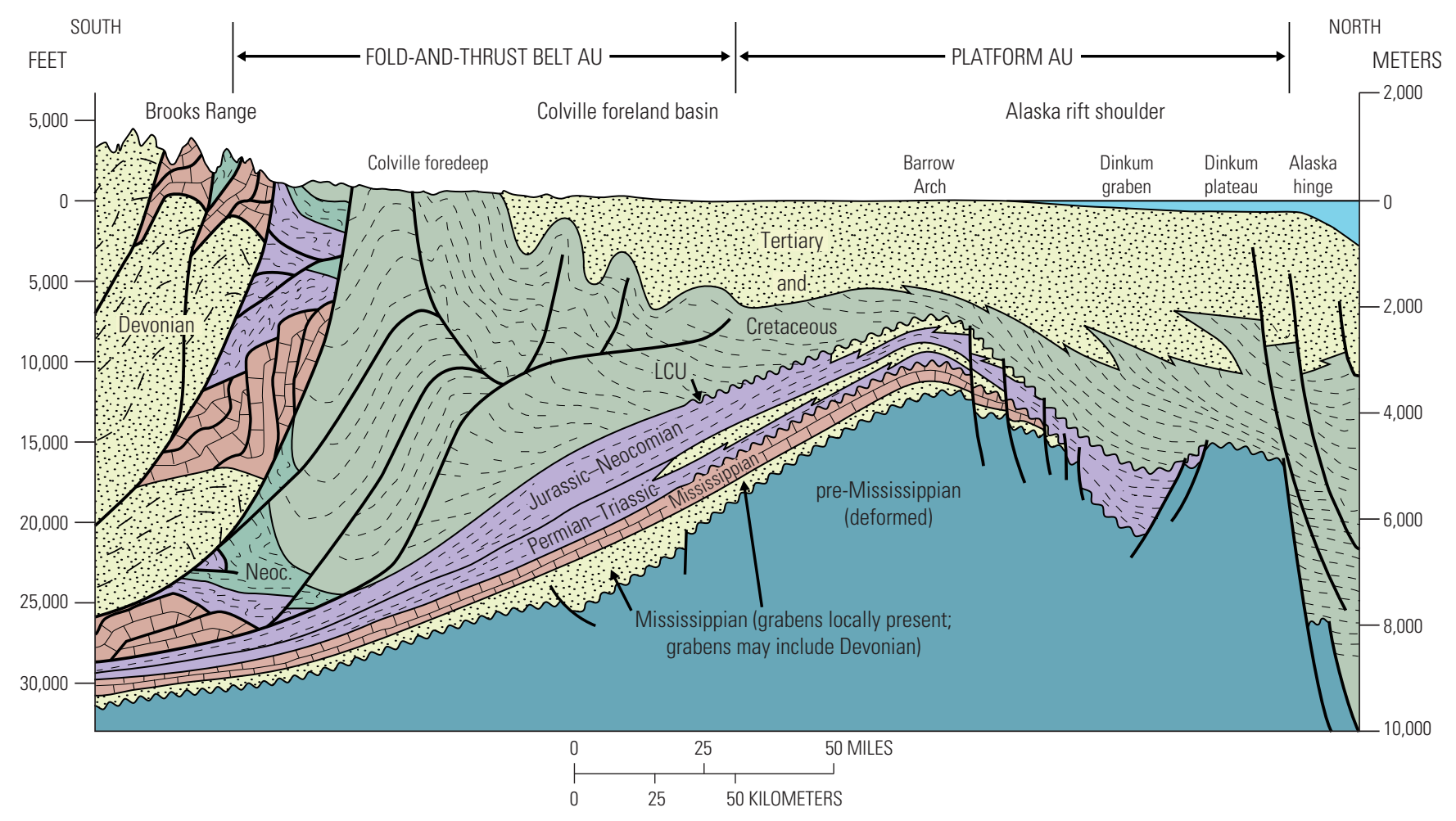

Figure 2. Generalized cross section showing stratigraphic and structural relations from the Brooks Range to the northern margin of the Alaska rift shoulder, central North Slope of Alaska. Note that Alaska rift shoulder in this area includes the Dinkum graben and plateau. AU, assessment unit; LCU, Lower Cretaceous unconformity. Location of cross section is shown in fig. 1. Modified from Bird and Bader (1987).

Cretaceous unconformity (fig. 2, LCU), considered to represent the climax of rift-shoulder uplift, perhaps accentuated as a forebulge in response to tectonic loading, and Franklinian basement subcrops the LCU in areas of maximum uplift (fig. 4A, $B$ ). Overlying the LCU, Lower Cretaceous-Tertiary foreland basin strata (Brookian sequence) generally thicken southward into the foredeep of the Colville basin and thin northward by onlap against the rift shoulder (Bird and Molenaar, 1992; Houseknecht and others, 2009a, b). The thickest part of the foreland-basin succession grades in age from Early Cretaceous beneath the western Alaska North Slope (ANS) to Tertiary beneath the eastern ANS, and the Alaska rift shoulder was progressively overstepped and buried from west to east by foreland-basin depositional systems (Molenaar, 1983; Bird and Molenaar, 1992; Houseknecht and others, 2009a, b, 2012b).

Although the Chukchi shelf is stratigraphically similar to the ANS, the Hanna trough - a Paleozoic failed rift filled by a thick succession of the Ellesmerian sequence - is a distinguishing feature (Sherwood and others, 2002; Thurston and Theiss, 1987). Ellesmerian strata in the Hanna trough thin eastward and grade into the passive-margin succession of the ANS and thin westward to an onlap pinchout against the Chukchi platform, an ancestral ridge of Franklinian basement whose axis lies near the U.S.-Russia maritime boundary (fig. 1). The Beaufortian sequence beneath the Chukchi shelf is similar to that of the ANS, except that it is punctuated by several unconformities (for example, Jurassic unconformity; fig. 3) that appear to be more significant than those to the east (Sherwood and others, 1998). The Brookian sequence beneath the Chukchi shelf comprises Lower Cretaceous (mostly Aptian-Albian) and Tertiary successions separated by a Paleocene unconformity (Sherwood and others, 1998). The Lower Cretaceous succession displays a regional geometry suggesting influences of both a sag basin developed above the Hanna trough and a foreland basin related to the Herald Arch and western Brooks Range. Lower Cretaceous strata grade eastward into foreland basin deposits of the ANS (Moore and others, 2002; Houseknecht and others, 2009a, b). The Tertiary succession, in contrast, is thickest in syndepositional grabens that open northward into the North Chukchi basin (fig. 1; Sherwood and others, 1998; Houseknecht and Bird, 2011). South of the rift shoulder, no apparent stratigraphic continuity exists between the Tertiary successions beneath the Chukchi shelf and the eastern ANS. Evidence suggests broad uplift of the western ANS during this time (Burns and others, 2007; Houseknecht and Bird, 2011; Houseknecht and others, 2011), segmenting the foreland into a Chukchi depocenter influenced by wrench tectonics and an eastern ANS depocenter influenced by contractional tectonics associated with the eastern Brooks Range. 
Figure 3. Generalized chronostratigraphy for the Arctic Alaska Province, based on the geology of the Alaska North Slope. Tectonostratigraphic sequence names shown in all caps at left. Oil-prone sourcerock systems discussed in text are indicated at right: 1, Triassic source-rock system, comprising the Shublik Formation and Triassic part of the Otuk Formation; 2, Jurassic source-rock system, comprising the lower Kingak Shale and Blankenship Member (B) of the Otuk Formation; and 3, Cretaceous-Paleogene source-rock system, comprising (3a) the Lower Cretaceous pebble shale unit and gamma-ray zone (GRZ), (3b) the Upper Cretaceous Seabee Formation, and (3c) lower Paleogene organic-rich tongues of the Canning Formation. LCU, Lower Cretaceous unconformity; JU, Jurassic unconformity; $F$, Fortress Mountain Formation; N, Nanushuk Formation; T, Tuluvak Formation. Oblique labels (Otuk Formation and B, Blankenship Member) indicate units that crop out in the Brooks Range frontal thrust belt and that represent southern distal facies equivalents of formations present beneath the Alaska North Slope. Arctic Alaska stratigraphy modified from Lerand (1973), Bird (1985, 2001), Hubbard and others (1987), and Mull and others (2003); ages from Gradstein and others (2004).

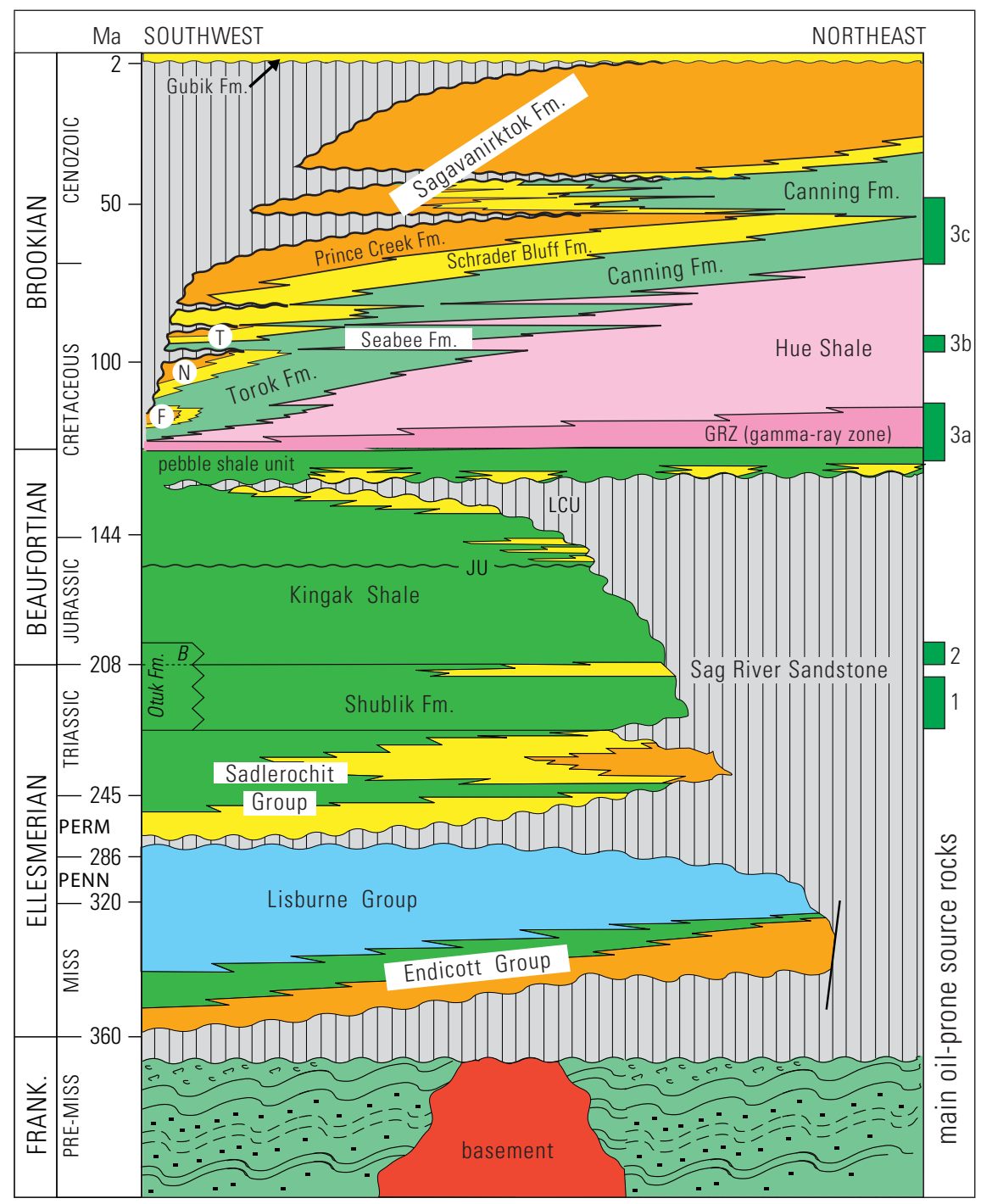

Figure 4 (page 5). Maps showing the three main oil-prone source-rock systems in the Arctic Alaska Province, with colors depicting the inferred original distribution of predominantly oil-prone (green) and gas-prone (yellow) kerogen. Maps are highly generalized and based on published information (see text) and paleogeographic reconstructions (Parrish and others, 2001a, b; Houseknecht and Bird, 2004, 2011). A, Triassic source-rock system, comprising the Shublik Formation across most of the map area and the Triassic part of the Otuk Formation in the southernmost part of the map area (frontal thrust belt of the Brooks Range). B, Jurassic source-rock system, comprising primarily the lower Kingak Shale across most of the map area and the Jurassic Blankenship Member of the Otuk Formation in the southernmost part of the map area (frontal thrust belt of the Brooks Range). The abrupt yellow-to-green boundary occurs at the shelf margin of the lower Kingak depositional sequence (Houseknecht and Bird, 2004). C, Cretaceous-Paleogene source-rock system, comprising primarily the pebble shale unit, gamma-ray zone (GRZ), and Seabee Formation south of the Alaska hinge and Cretaceous and Paleogene condensed mudstones north of the Alaska hinge (Houseknecht and Bird, 2011; Houseknecht and others, 2012b). Pink shading in $A$ and $B$ shows areas of greatest uplift of rift shoulder during Jurassic-Early Cretaceous; Triassic and Jurassic source rocks are absent by erosion in those areas. Note that Triassic and Jurassic source rocks are probably absent or buried to extreme depths north of the Alaska hinge. Presence of Cretaceous-Paleogene source rocks north of Alaska hinge is inferred on the basis of paleogeographic reconstructions (Houseknecht and Bird, 2011). AU, assessment unit; JU, Jurassic unconformity; LCU, Lower Cretaceous unconformity; TAPS, Trans Alaska Pipeline System; TST, Transgressive Systems Tract (Houseknecht and Bird, 2004). 


\section{A. Triassic source-rock system}

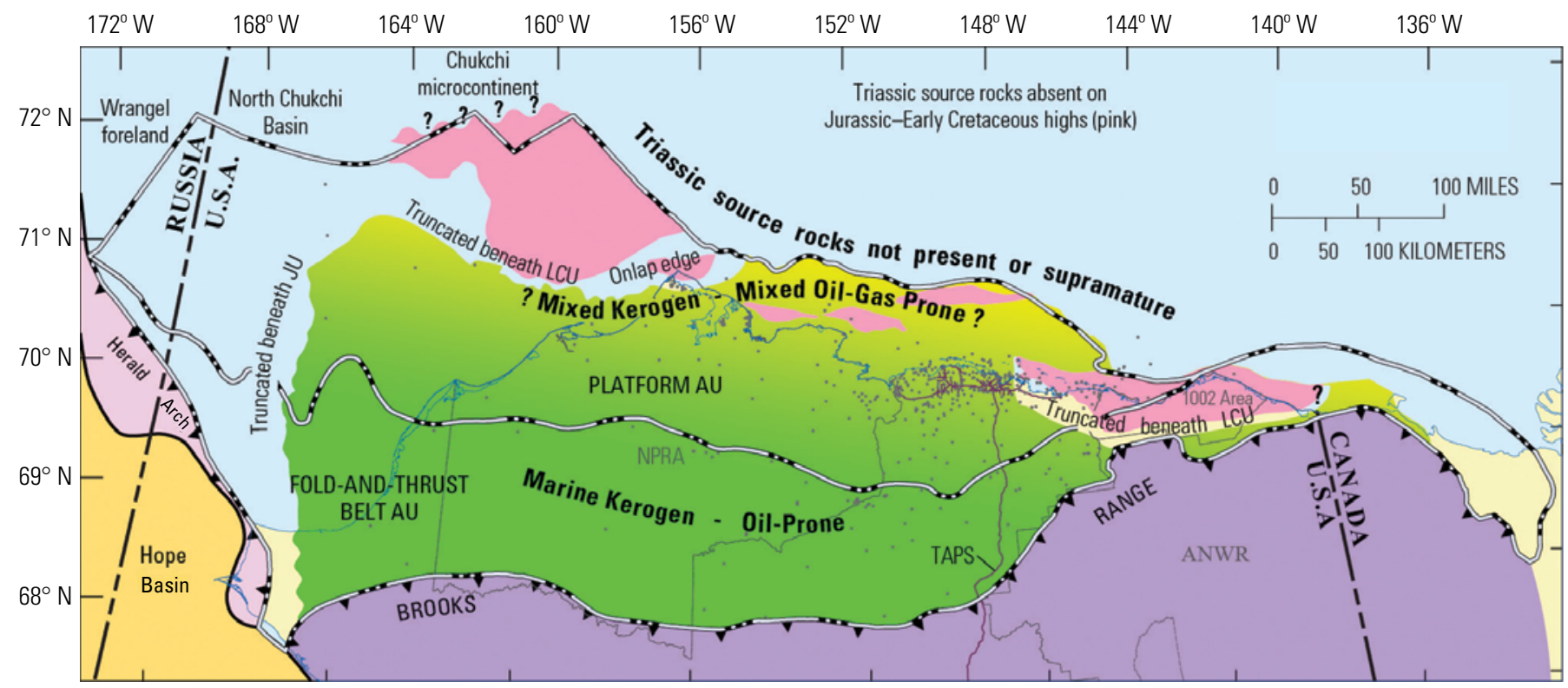

\section{B. Jurassic source-rock system}

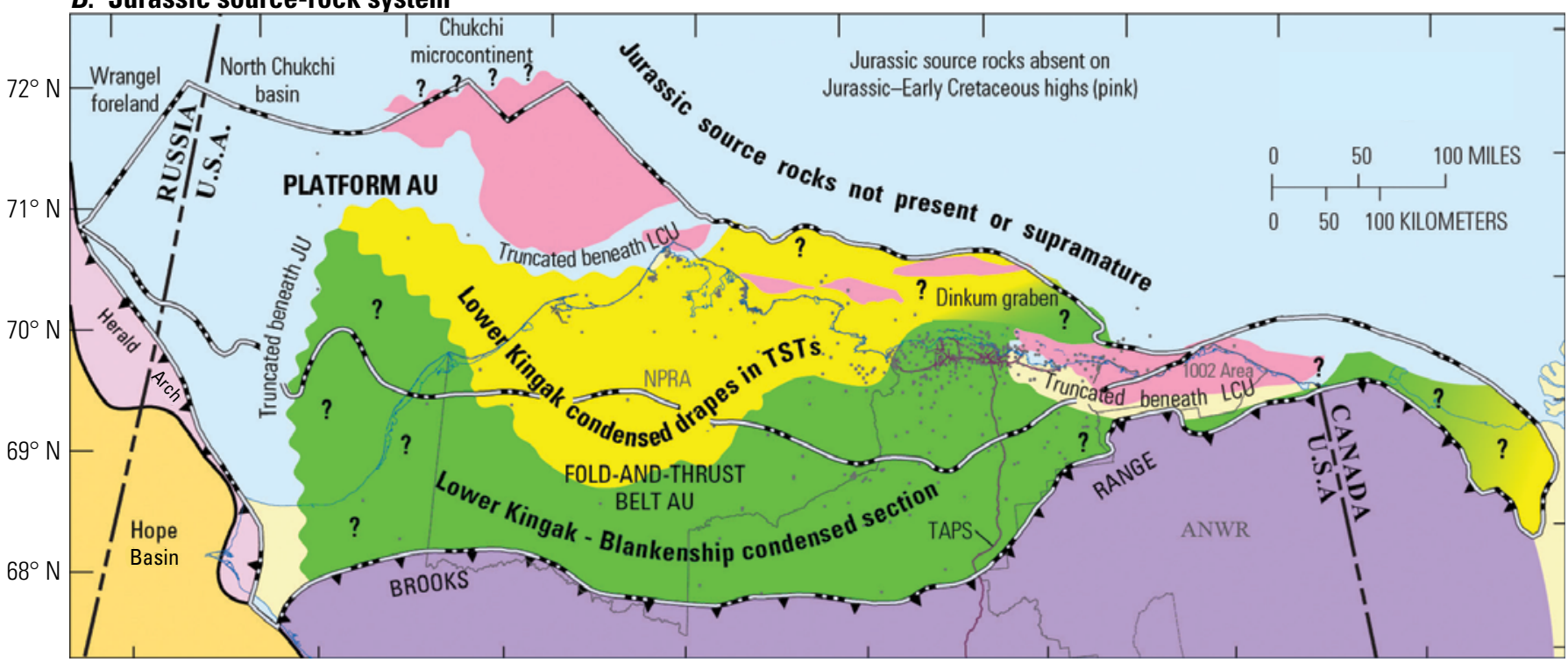

\section{Cretaceous-Paleogene source-rock system}

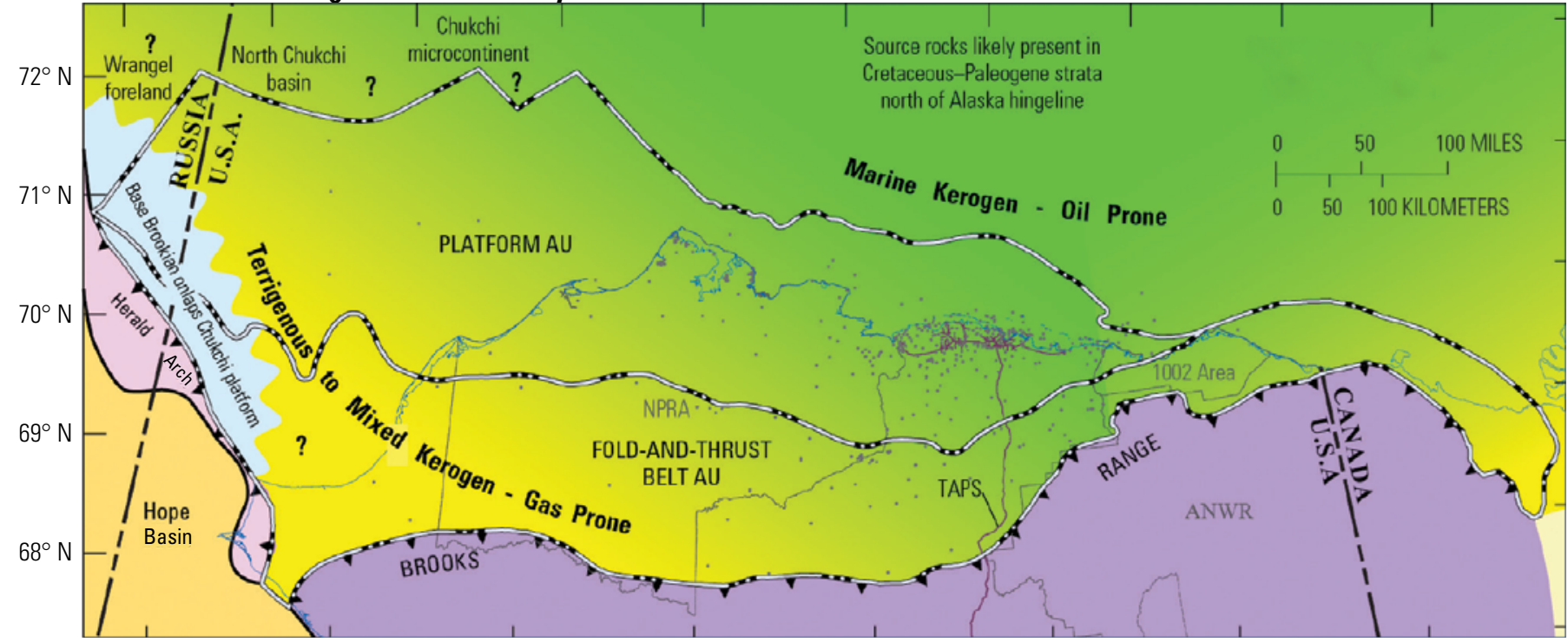




\section{Source-Rock Systems}

Multiple petroleum systems have been identified in Arctic Alaska, and many oil accumulations appear to be mixtures of oil expelled from two or more source rocks (Magoon and others, 2003; Peters and others, 2008). The regional source-rock potential of Arctic Alaska is considered within a framework of three source-rock systems: Triassic, Jurassic, and Cretaceous-Paleogene. The Triassic source-rock system includes the Shublik Formation and its southern distal equivalent, the Triassic part of the Otuk Formation, which crops out in the frontal thrust belt of the Brooks Range (Mull and others, 1982; Kupecz, 1995; Masterson, 2001; Parrish and others, 2001a, b; Peters and others, 2006). The Jurassic sourcerock system includes the lower Kingak Shale and its southern distal equivalent, the Jurassic Blankenship Member of the Otuk Formation, which crops out in the frontal thrust belt of the Brooks Range (Seifert and others, 1980; Mull and others, 1982; Masterson, 2001; Houseknecht and Bird, 2004; Peters and others, 2006). Although both the Shublik and Kingak source rocks may be present in grabens along the northern margin of the province, it is unlikely that either is present north of the hingeline because the Amerasia Basin was not yet open when those source rocks were deposited (Houseknecht and others, 2012b). The Cretaceous-Paleogene source-rock system includes the Hauterivian pebble shale unit, the Lower Cretaceous gamma-ray zone (GRZ) of the Hue Shale, the Upper Cretaceous (mostly Turonian) Seabee Formation, and Paleogene organic-rich beds in the Canning Formation (fig. 3; Mull and others, 2003; Macquaker and Keller, 2005; Peters and others, 2006; Houseknecht and Bird, 2011; Houseknecht and others, 2012b).

The present character of these source-rock systems has been documented in the most heavily explored part of the Arctic Alaska Province (see, for example, Claypool and Magoon, 1985; Creaney and Passey, 1993; Lillis and others, 1999; Magoon, 1994; Magoon and Bird, 1988; Magoon and Claypool, 1985; Magoon and others, 1987, 1999; Masterson, 2001; Threlkeld and others, 2000), and the original (prematuration) character has been inferred for the same area (Peters and others, 2006). However, the source-rock quality across much of the province remains poorly known because of limited data. Outcrop samples from the Brooks Range frontal thrust belt (Dow and Talukdar, 1995; Dow, 1998; Mull, 2000, 2009) indicate that the Triassic and Jurassic source rocks originally were rich (higher total organic carbon content) and oil-prone (higher hydrogen index values). In contrast, thrustbelt outcrop samples of the pebble shale and GRZ display highly variable character; they tend to be lean and gas-prone across much of the thrust belt but locally are rich and oil-prone (Dow and Talukdar, 1995; Dow, 1998; Mull, 2000, 2009).

Highly generalized maps depicting the original character of these three source-rock systems are shown in figure 4 . The Triassic and Jurassic source-rock systems were deposited on a south-facing (present coordinates) passive continental margin and, when the character of outcrop samples from the Brooks Range frontal thrust belt are considered, they appear originally to have graded southward to facies that are richer (higher total organic carbon content) and more oil-prone (higher hydrogen index values) (fig. 4A, B; Dow and Talukdar, 1995; Kupecz, 1995; Dow, 1998; Mull, 2000, 2009; Masterson, 2001; Parrish and others, 2001a, b; Peters and others, 2006). The Lower Cretaceous pebble shale unit and GRZ, deposited during and after the opening of the Canada Basin and the onset of Brooks Range tectonism and foreland basin development, appear originally to have been richer and more oil-prone towards the east and north (fig. 4C; Dow and Talukdar, 1995; Dow, 1998; Mull, 2000, 2009; Peters and others, 2006). However, organicrich and oil-prone source rocks also have been documented locally in outcrops of the pebble shale unit and GRZ along the western part of the Brooks Range frontal thrust belt (C.G. Mull, Alaska Division of Geological and Geophysical Surveys, written commun., 2009) ${ }^{1}$, so exceptions to the generalized regional trends have been documented. Although not confirmed by drilling, the potential exists for rich and oilprone Cretaceous and Paleogene source rocks in the Canada Basin, north of the Alaska rift shoulder (Houseknecht and Bird, 2011; Houseknecht and others, 2012b), and this potential is reflected in figure $4 C$.

In addition to the major source-rock systems discussed above, oil-prone source rocks are known to occur in the upper part of the upper Paleozoic Lisburne Group (fig. 3), and several Arctic Alaska oil accumulations are inferred to have been partly charged from Lisburne source rocks (Magoon and others, 2003; Dumoulin and others, 2008a, b, 2011). Moreover, gas-prone mudstones and local coals occur in strata ranging in age from Mississippian (Endicott Group) to Paleogene (Canning, Prince Creek, and Sagavanirktok Formations) (fig. 3).

Thermal maturity of these source rocks generally reflects the distribution and thickness of Cretaceous and younger foreland-basin and Beaufort passive-margin deposits (fig. 5). All source rocks in the foredeep are overmature with respect to the oil window, are mostly mature on the northern flank of the foreland basin, and are mostly early-mature to immature

\footnotetext{
${ }^{1}$ Notes regarding source-rock character of the Otuk Formation, the pebble shale unit, and the GRZ in outcrops of the Brooks Range frontal thrust belt and based on work conducted by the Alaska Department of Natural Resources, Division of Geological and Geophysical Surveys.
} 
on the rift shoulder (figs. 5, 6). Modeling of burial history and hydrocarbon generation indicates that most oil generation occurred during the Early to Middle Cretaceous in the western to central part of the province and during the Paleogene in the eastern part of the province; these maturation dates correspond to times when the thickest foreland basin successions were deposited (Houseknecht and others, 2012b). In the Canada Basin, maturation of all source rocks generally occurred during the Paleogene-Neogene, except in a depocenter immediately north of the Alaska rift shoulder along the northeast Chukchi margin where maturation of the oldest source rocks may have occurred during the Early Cretaceous (Houseknecht and others, 2012b).

Throughout the history of hydrocarbon generation, the Alaska rift shoulder remained a structurally high focus for migration of hydrocarbons generated both in the Arctic Alaska Province and in the southern Canada Basin. Most discovered oil accumulations (including the giant Prudhoe Bay field) and many discovered gas accumulations occur along the rift shoulder and its flanks.

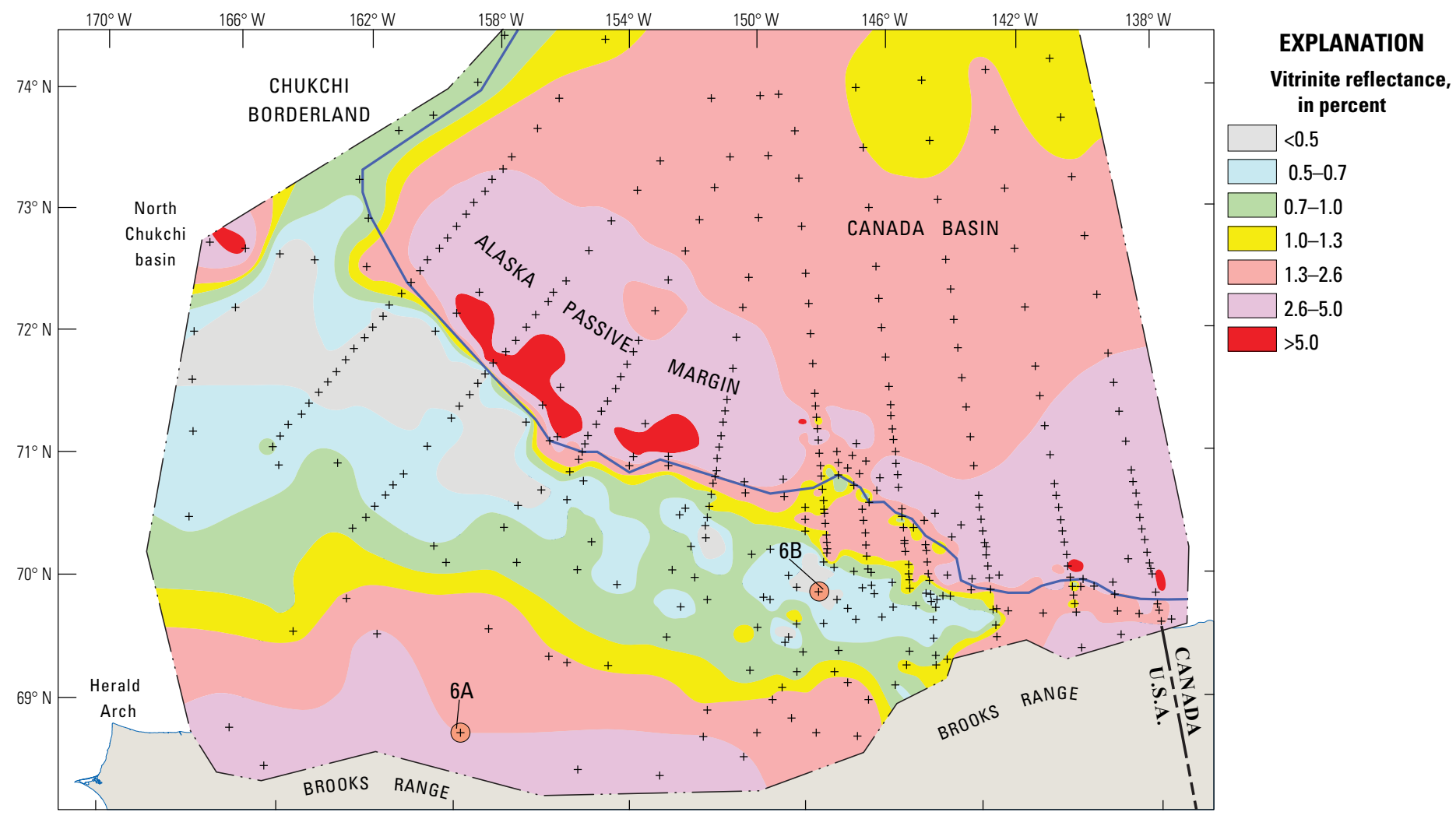

Figure 5. Map of thermal maturity at the base of the Brookian sequence across the Arctic Alaska Province and the southern Canada Basin. This map is derived from thermal history modeling and honors empirical vitrinite reflectance data from 97 exploration wells in the Arctic Alaska Province. Crosses are exploration wells and pseudowells used for modeling. Petroleum systems plots for circled wells with labels are shown in figure 6 . Maturity values greater than 3 percent vitrinite reflectance are approximate because those values exceed the validity range of kinetics used for calculation. Location of the Alaska hinge is shown by the heavy blue line. Most empirical data from the compilation of Johnsson and others (1993); vitrinite reflectance calculated by using kinetics of Burnham and Sweeney (1989). Modified from Houseknecht and others (2012b). 


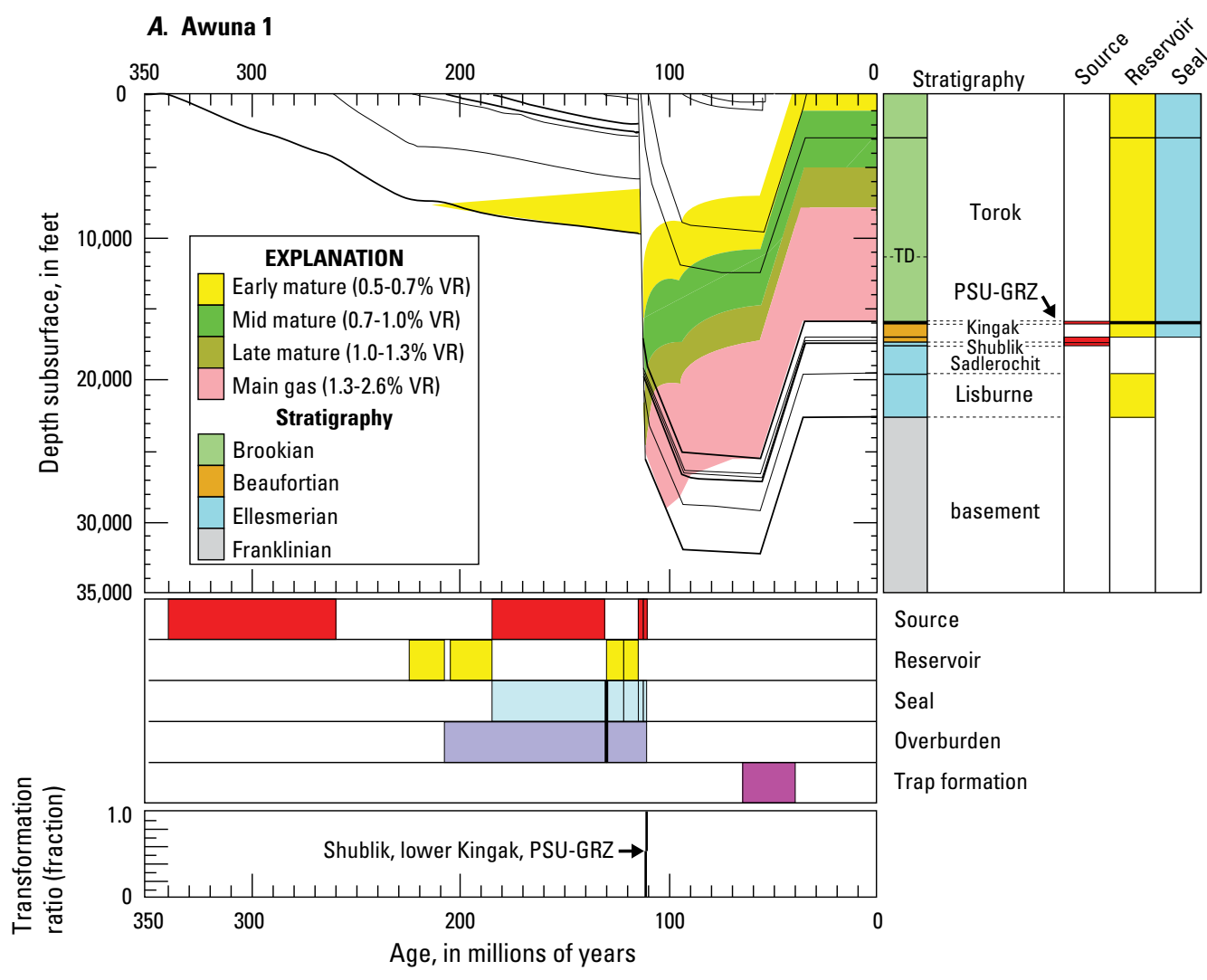

B. West Kuparuk 3-11-11

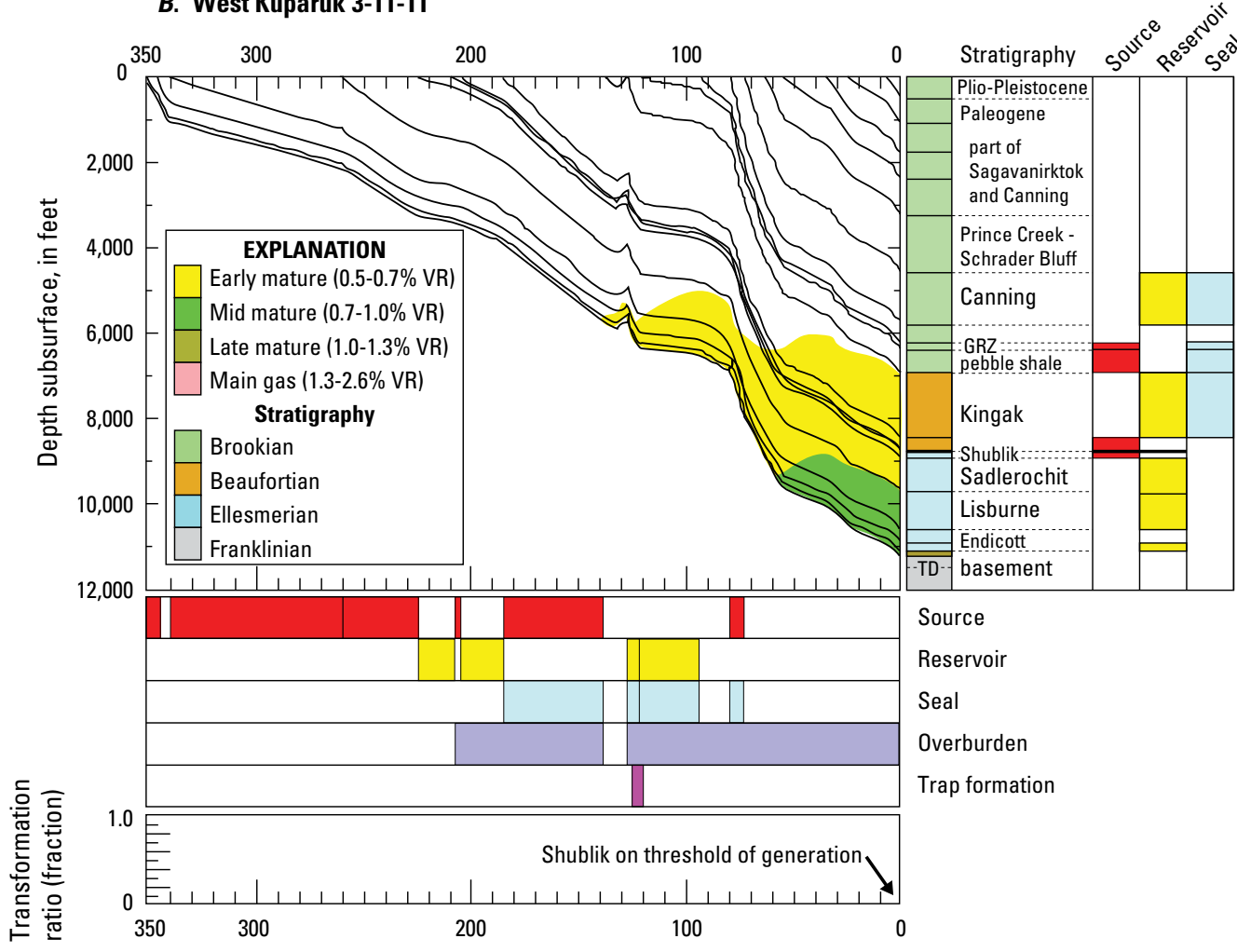

Figure 6. Petroleum systems plots for two wells in the Arctic Alaska Province. A, Well Husky Awuna 1, representative of burial and thermal maturation history in the Arctic Alaska Fold-andThrust-Belt Assessment Unit. Stratigraphy below total depth of well (TD in stratigraphic column) was estimated from seismic data. Timing of indicated trap formation reflects Paleogene deformation and does not include development of stratigraphic traps and pre-Paleogene structural traps. Note rapid and nearly simultaneous oil generation in all three main source-rock systems, as expressed by plot of time versus transformation ratio. $B$, Well Mobil West Kuparuk 3-1111 , representative of burial and thermal maturation history in the Arctic Alaska Platform Assessment Unit. Well penetrated entire stratigraphic section and reached total depth (TD) in Franklinian basement. Timing of indicated trap formation reflects development of the Lower Cretaceous unconformity truncation trap (main trap at Prudhoe Bay) and does not include other stratigraphic and structural trap development. Note that none of the main oil-prone source rocks has generated oil at this location, as indicated by the plot of time versus transformation ratio. In the stratigraphic column of both plots, only major stratigraphic units are named, whereas burial history plots include more detailed subdivision of strata. Well locations are shown in figures 5 , 7, and 8. GRZ, gamma-ray zone; PSU, pebble shale unit; VR, vitrinite reflectance. 


\section{Arctic Alaska Platform Assessment Unit}

The Arctic Alaska Platform Assessment Unit contains numerous discovered accumulations that have been produced (Houseknecht and Bird, 2006; Alaska Division of Oil and Gas, 2007). This level of exploration places the platform AU into uncertainty category 1 on the scale used by the USGS for the Circum-Arctic Resource Appraisal. That scale of uncertainty places each AU into one of five categories based on data density and degree of exploration, as follows: 1, producing fields; 2, discovered accumulations; 3 , exploration wells; 4, seismic data; and 5, no seismic data (Charpentier and Gautier, 2011).

\section{Assessment Unit Description}

The Arctic Alaska Platform AU extends from the northern limit of the Brooks Range foothills fold-and-thrust belt on the south to the north margin of the Alaska rift shoulder on the north and from the axis of the Chukchi platform (near the U.S.-Russia maritime boundary) on the west to a wedgeout on the east where the Brooks Range tectonic front has overridden the rift shoulder (fig. 7; Dietrich and Lane, 1992). The AU encompasses an area of 193,000 $\mathrm{km}^{2}$.

The platform AU includes the Alaska rift shoulder (whose crest is the Barrow Arch) and the Arctic-Chukchi platform, including much of the Chukchi shelf. The tectonic history of the AU includes a late Paleozoic through early Mesozoic phase characterized by a south-facing passive continental margin transected in the west by a Devonian(?)-Mississippian failed rift (fig. 1, Hanna trough), an episode of extension and rifting (mostly along the northern margin of the AU) in the Jurassic through early Cretaceous, and development of a foreland basin during the Cretaceous and Tertiary related to tectonism along the Chukotka and Brooks Range belts (Moore and others, 1994; Houseknecht and Bird, 2011). Petroleumprospective strata are mostly Mississippian and younger, although postulated lower Paleozoic strata in the northeast Chukchi Basin (Sherwood and others, 1998) also are included.

The AU contains several oil-prone source-rock systems that have been demonstrated to have charged discovered oil and gas accumulations (Masterson, 2001; Magoon and others, 2003; Peters and others, 2006, 2008). The main oil source rocks include the Triassic Shublik Formation, Jurassic lower Kingak Shale, and Lower Cretaceous pebble shale unit and GRZ (fig. 3). Additional oil-prone source rocks are locally present in upper Paleozoic and perhaps in Paleogene strata. Gas-prone source rocks are present in several formations spanning upper Paleozoic through Paleogene strata.

More than two dozen accumulations have been discovered in the AU, including at least 15 oil and 2 gas accumulations larger than 50 million barrels of oil equivalent (MMBOE) plus numerous smaller oil and gas accumulations
(Jamison and others, 1980; Carman and Hardwick, 1983; Melvin and Knight, 1984; Hohler and Bischoff, 1986; Masterson and Paris, 1987; Werner, 1987; Wicks and others, 1991; Masterson and Eggert, 1992; Jameson, 1994; Gingrich and others, 2001; Craig and Sherwood, 2004; Houseknecht and Bird, 2006; Hudson and others, 2006). Through 2005, about 15 billion barrels of oil (BBO) have been produced with reserves of $6.7 \mathrm{BBO}$ and 35 trillion cubic feet of gas (TCFG).

\section{Geologic Analysis of Assessment Unit Probability}

Although this $\mathrm{AU}$ is the most intensely explored in Arctic Alaska, most exploration has been concentrated in a relatively small part of the AU, onshore and nearshore along the trend of the rift shoulder (fig. 7). Considering the history of discovery in this AU and the vast area that is lightly explored, the probability that the Arctic Alaska Platform AU contains at least one undiscovered accumulation of at least $50 \mathrm{MMBOE}$ is considered to be 100 percent (appendix 1). At the time of this assessment, the AU contained 10 producing fields, including the largest conventional oil field in North America (Prudhoe Bay), and several additional discoveries larger than 50 MMBOE.

\section{Charge}

Demonstrated source rocks that occur within this AU, as well as in the fold-and-thrust belt AU to the south, include the Triassic Shublik Formation, Jurassic lower Kingak Shale, and Lower Cretaceous pebble shale unit and GRZ. Mixing of oil from these source rocks is common in this AU (Magoon and others, 2003; Peters and others, 2008). Regional seismic, well, and outcrop data and burial history modeling indicate that petroleum generation was controlled by burial related to filling of the Colville foreland basin, which began in the southwest in the Early Cretaceous (about 120-110 Ma) and progressed eastward to the middle Paleogene (about $45 \mathrm{Ma}$ ). As foreland basin fill prograded northward across the subsiding rift shoulder, petroleum generation occurred north of the rift shoulder, where a thick prism of Brookian sediment was deposited (fig. 5). Generally, regional migration pathways likely followed stratigraphic bedding and unconformities updip toward the Barrow Arch, but local pathways are postulated to be controlled by faults in the entire stratigraphic section and by clinoforms in the Beaufortian and Brookian sequences. Moreover, Paleogene uplift in the northwestern part of the AU and regional tilting of the Barrow Arch, probably induced by tectonic loading by the Brooks Range in the east, resulted in spilling and remigration in several areas (Jones and Spears, 1976; Wallace and Hanks, 1990; O'Sullivan and others, 1993; Masterson, 2001; Potter and others, 2004; Houseknecht and others, 2011). 


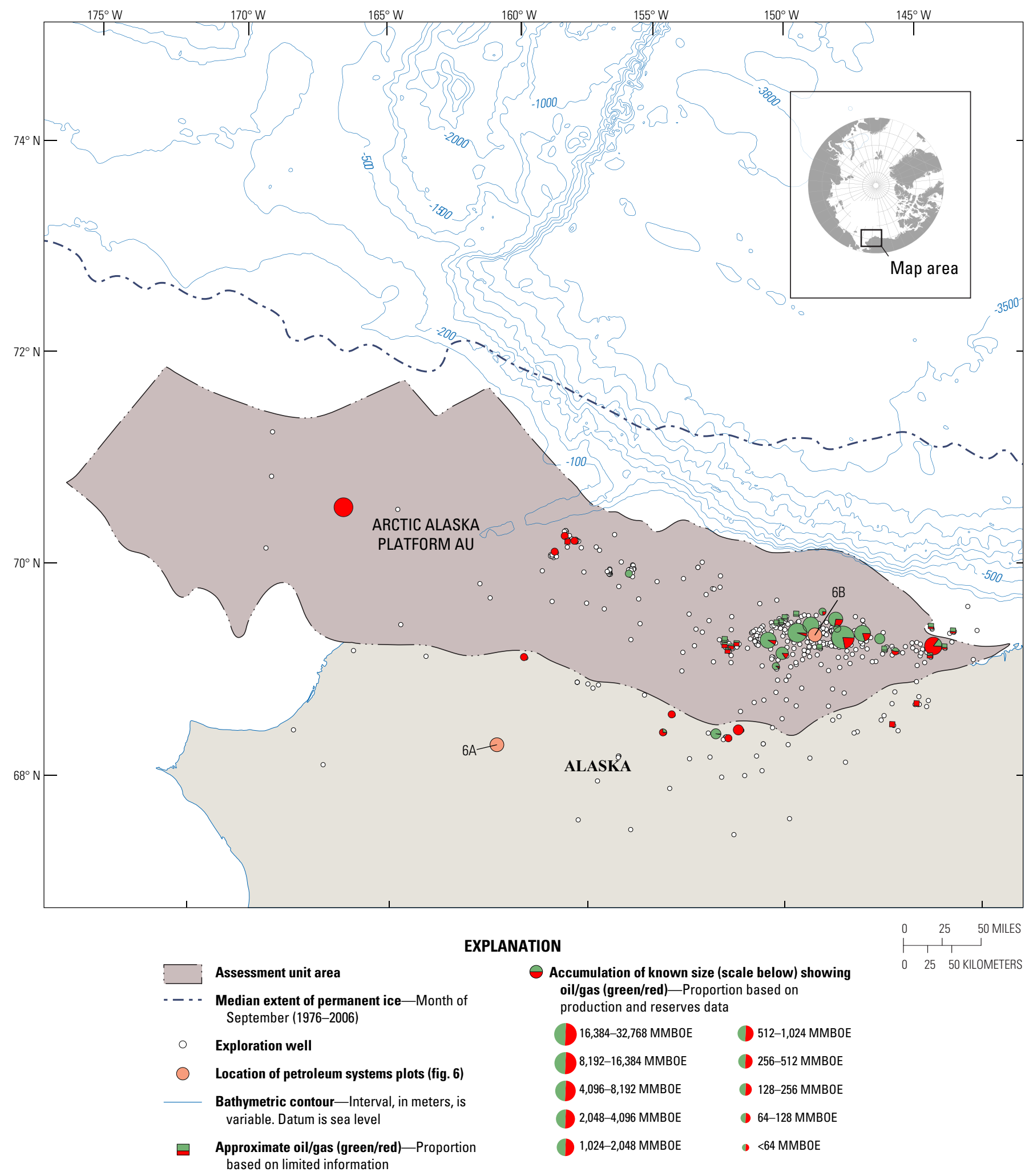

Figure 7. Map of Arctic Alaska Platform Assessment Unit showing locations of exploration wells and known accumulations of oil and gas. Known accumulation bubbles are scaled to show estimated total known resource (produced plus reserves) and are divided to show proportion of liquid (crude oil plus condensate) and gas. Reserves data are from Houseknecht and Bird (2006) and Alaska Division of Oil and Gas (2007). 


\section{Rocks}

The dominant reservoir lithology in this AU is sandstone, although upper Paleozoic carbonate reservoirs (Lisburne Group) are locally important. Nearly every sandstone unit is known to contain hydrocarbons somewhere in the AU. The greatest volumes of known petroleum resources (cumulative production plus reserves) are reservoired in fluvial-deltaic sandstone of the Ivishak and Kekiktuk Formations (Triassic and Mississippian, respectively; Melvin and Knight, 1984; Shanmugam and Higgins, 1988; Crowder, 1990), the shallow marine sandstone of the Kuparuk Formation and stratigraphically equivalent units (Early Cretaceous; Carman and Hardwick, 1983; Masterson and Paris, 1987; Werner, 1987; Masterson and Eggert, 1992), and the Upper Jurassic part of the Kingak Shale (Houseknecht and Bird, 2004). The largest known accumulations (Prudhoe Bay, Kuparuk, Point Thomson, Burger) occur in combination structural-stratigraphic traps related to rifting, but an increasing number of accumulations are known to occur in purely stratigraphic traps in both deep marine facies (Meltwater, Tarn, Nanuq) and shallow marine facies (Alpine, Fiord, Rendezvous, Moose's Tooth, Tabasco) (Gingrich and others, 2001; Houseknecht and Schenk, 2007). Seals are provided by marine shale.

\section{Timing and Preservation}

Oil generation began in the southern and western parts of the Arctic Alaska Province in the Early Cretaceous (fig. 6A) and progressed eastward and northward through the Tertiary (Houseknecht and others, 2012b). Onshore, generation probably ended during the late Eocene (about $45 \mathrm{Ma}$ ) but may still be ongoing offshore in the eastern part of the AU where sedimentation continues on the shelf of the Beaufort Sea (Houseknecht and others, 2012b).

There was potential for loss of trapped hydrocarbons during the Paleogene, when the Barrow Arch tilted downward to the east, apparently as the result of tectonic loading by the northward advance of the northeast Brooks Range. This regional tilting caused spilling of oil from the giant Prudhoe Bay accumulation and remigration of that oil to shallower traps (Jones and Spears, 1976; Masterson, 2001). Some of those traps are so shallow that the oil has been biodegraded, resulting in multibillion-barrel accumulations of heavy oil in the Prudhoe Bay-Kuparuk area. Also during the Paleogene, the western part of the Alaska rift shoulder was uplifted (Houseknecht and others, 2011), likely resulting in both oil displacement from traps by gas expansion and regional updip migration of dry gas from the foredeep. It is unknown whether tilting of the Barrow Arch and uplift of the western part of the rift shoulder share a common geologic cause.

\section{Analogs Used for Assessment}

Assessment input was influenced strongly by the geology, sizes, and numbers of discovered accumulations in the AU and by the assessments of undiscovered resources conducted by the USGS and U.S. Department of the Interior, Minerals Management Service (MMS), which were largely based on the mapping of favorable trap geometries from reflection seismic data (ANWR Assessment Team, 1999; Bird and others, 2005; Minerals Management Service, 2006; Houseknecht and others, 2010). In those assessments a total of 69 plays were identified and assessed within the area considered in the Arctic Alaska Platform AU. From those assessments, the mean value of undiscovered resources and number and sizes of undiscovered pools larger than 50 MMBOE were tabulated and used as a consideration for completing the assessment input. Because of the unique tectonic history of the Arctic Alaska Platform AU (rift shoulder and foreland basin overlap in time and space), analogs were difficult to identify in the USGS World Analog Database (Charpentier and others, 2008). A search of extensional structural setting plus continental crustal system, culled to remove AUs with compressional, thrust-fault, wrench-fault, and salt-related structures, provided additional guidance for constraining possible numbers and sizes of accumulations. The resulting analog set (table 1) contains 34 AUs in which the predominant trap system is basement-involved block structures.

\section{Assessment Inputs}

\section{Number of Accumulations}

Considering that this AU is one of the most prolific oil Provinces in North America, that only a small part of the AU has been explored, and that numerous potential traps have been identified in seismic data, values of 25, 150, and 300 were selected for the minimum, median, and maximum number of undiscovered accumulations of at least $50 \mathrm{MMBOE}$ (appendix 1). These inputs equate to densities that are within the distribution of the analog set.

\section{Oil-to-Gas Mix}

The minimum, median, and maximum values for the oil-to-gas ratio were set at $0.3,0.6$, and 0.8 (appendix 1) based on the ratio of oil-to-gas accumulations in the discovered population (larger than $50 \mathrm{MMBOE}$ ) and the spatial distribution of oil-versus gas-prone source rocks and thermal maturity across the AU. 


\section{The 2008 Circum-Arctic Resource Appraisal}

Table 1. Analog assessment units used to constrain input parameters for the Arctic Alaska Platform Assessment Unit. Analog data from Charpentier and others (2008).

[AU, assessment unit]

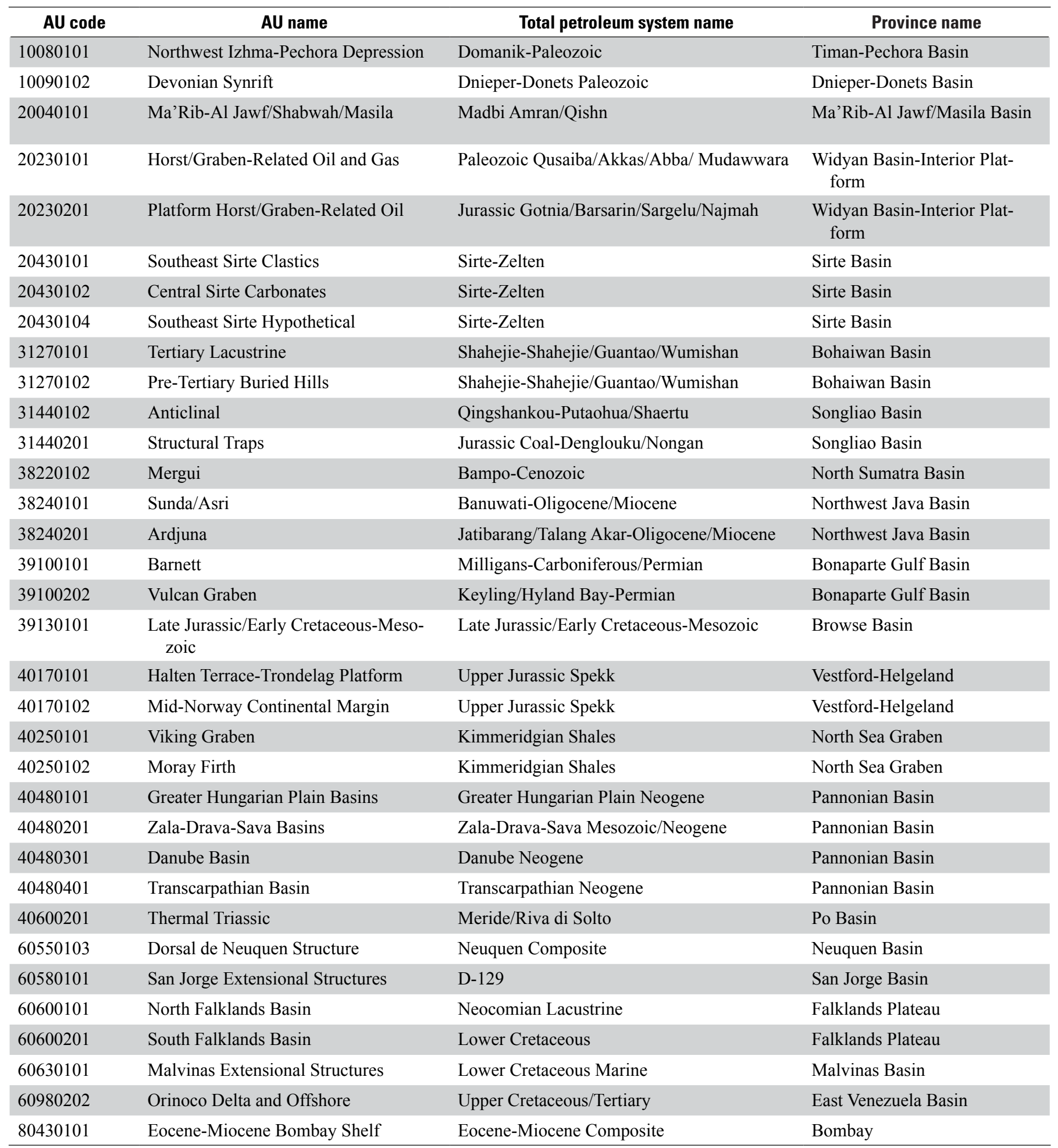




\section{Accumulation Size Distribution}

The median and maximum oil accumulation sizes were set at 150 and 8,000 MMBO, respectively (appendix 1). The median value was based on the sizes of discovered accumulations in the $\mathrm{AU}$ and the sizes of potential traps identified in seismic data. The maximum value was set to approximately half the size of the Prudhoe Bay accumulation. These input values are within the analog distributions, although they fall in the upper parts of those distributions. Median and maximum input values of 0.9 and $50 \mathrm{TCF}$ (appendix 1) were set for gas accumulation sizes based mostly on the range of sizes of potential traps identified on seismic data. The only known gas accumulations in this AU whose sizes are well constrained are those associated with large oil accumulations (for example, Prudhoe Bay), and the sizes of nonassociated gas accumulations are poorly known (Houseknecht and Bird, 2006).

\section{Estimated Maximum Accumulation Size}

Maximum accumulation sizes of 1 to $2 \mathrm{BBO}$ and 12 to 15 TCFG were selected based on the size distribution of discovered accumulations and the largest accumulation sizes assessed by MMS and USGS using a large seismic database to constrain trap sizes. These maximum sizes, which did not enter directly into the volumetric calculations, were used to judge the reasonableness of the results of statistical analysis.

\section{Ancillary Properties and Co-Product Ratios}

Data from discovered pools in this AU and from geochemistry of source rocks were used to establish input values for these parameters.

\section{Results}

Probabilistic estimates of volumes of undiscovered, technically recoverable hydrocarbons for the Arctic Alaska platform AU are summarized in table 3. These results include mean estimates of nearly $28 \mathrm{BBO}$, more than $37 \mathrm{TCF}$ associated gas, and more than $120 \mathrm{TCF}$ nonassociated gas.

\section{Arctic Alaska Fold-and-Thrust Belt Assessment Unit}

The Arctic Alaska Fold-and-Thrust Belt AU has been lightly explored but includes oil and gas discoveries larger than the minimum considered in the CARA. This level of exploration places the Arctic Alaska Fold-and-Thrust Belt AU into uncertainty category 2 on the scale used by the USGS for the Circum-Arctic Resource Appraisal (Charpentier and Gautier, 2011).

\section{Assessment Unit Description}

The Arctic Alaska Fold-and-Thrust Belt AU extends from the northern margin of the Brooks Range and Herald Arch on the south to the northern limit of significant detachment folding that marks the boundary with the Arctic Alaska platform AU (fig. 8). The eastern quarter of the AU, where the Brooks Range tectonic front has overridden the Alaska rift shoulder, is bounded on the north by growth-faulted and contractionally deformed Tertiary strata deposited north of the rift shoulder (part of the Canning-Mackenzie Deformed Margin AU of the Amerasia Basin Province; Houseknecht and others, 2012a [ this volume]). The AU encompasses an area of $156,000 \mathrm{~km}^{2}$.

As defined, the AU includes the southern parts of the Chukchi shelf, Hanna trough, and Colville foreland basin, plus the entire frontal thrust belt of the Brooks Range in northeastern Alaska and northwestern Canada (fig. 8). This AU is characterized by detachment folds and thrust faults related to Brooks Range tectonism. The detachment level generally steps down the stratigraphic section southward toward the Brooks Range, from Cretaceous-Tertiary foreland basin strata in the north, through upper Mesozoic-Lower Cretaceous rift-related strata, and into lower Mesozoic-upper Paleozoic passive margin strata in the south (Moore and others, 1994, 2004; Potter and others, 2004). Petroleum-prospective strata span the stratigraphic section from upper Paleozoic through Tertiary.

The AU contains several oil-prone source-rock systems that have been shown to have charged discovered oil and gas accumulations (Magoon and others, 2003; Peters and others, 2008). The main oil-prone source rocks include the Triassic Shublik Formation, the Jurassic lower Kingak Shale, and the Lower Cretaceous pebble shale unit and GRZ (fig 3). The Triassic-Lower Jurassic Otuk Formation - the distal stratigraphic equivalent of the Shublik Formation and lower Kingak Shale - is an important component of the source-rock system in the southern part of the AU where it is present on thrust sheets. Source-rock facies gradational between the Shublik Formation and lower Kingak Shale on the north and the Otuk Formation in the south may be present in autochthonous positions deeply buried beneath the disturbed belt of the frontal Brooks Range. Locally, the Otuk Formation in outcrop occurs at levels of thermal maturity that are in the oil window (Dow and Talukdar, 1995; Dow, 1998; Mull, 2000, written commun., 2009). Additional oil-prone source rocks are locally present in upper Paleozoic strata, most notably the Kuna Formation of the Lisburne Group. Gas-prone source rocks are present in several formations spanning upper Paleozoic through Tertiary strata.

Several gas accumulations and one oil accumulation have been discovered in the AU (Houseknecht and Bird, 2006). Only the Gubik gas accumulation (about $600 \mathrm{BCF}$ ) and the Umiat oil accumulation (about $70 \mathrm{MMBO}$ ) are larger than the minimum size considered in this assessment. However, most of 


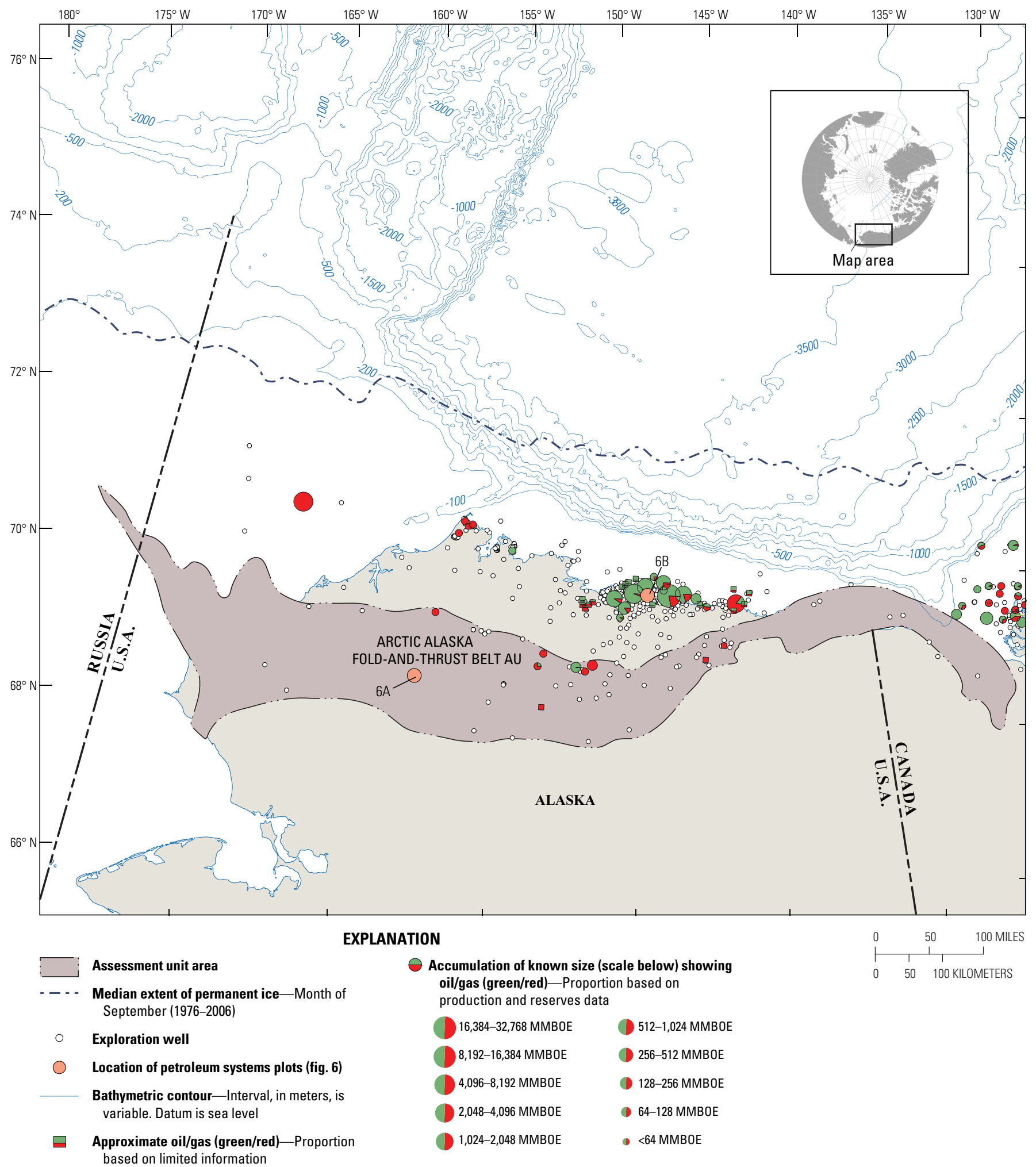

Figure 8. Map of Arctic Alaska Fold-and-Thrust Belt Assessment Unit showing locations of exploration wells and known accumulations of oil and gas. Known accumulation bubbles are scaled to show estimated total known resource (produced plus reserves) and are divided to show proportion of liquid (crude oil plus condensate) and gas. Reserves data for Alaska are from Houseknecht and Bird (2006) and Alaska Division of Oil and Gas (2007) and for Canada are from Osadetz and others (2005), except for a new discovery reported by Johnston (2007). 
the discovered gas accumulations are too poorly characterized to determine their size. No commercial production has occurred in this $\mathrm{AU}$, although about 40,000 barrels of oil was produced for local consumption and testing at Umiat prior to 1953 (Molenaar, 1982).

\section{Geologic Analysis of Assessment Unit Probability}

The likelihood that the Arctic Alaska Fold-and-Thrust Belt AU contains at least one undiscovered accumulation of at least $50 \mathrm{MMBOE}$ is considered to be 100 percent (appendix 2) based on the occurrence of two discoveries greater than the minimum size, the large number of prospects that are evident in seismic data and surface geologic map patterns, and the underexplored status of the AU. Many untested prospects involve anticlines, including relatively simple detachment anticlines and more complex thrust-faulted anticlines (see, for example, Oldow and others, 1987; Bird, 1988; Moore and others, 2004; Potter and others, 2004). Stratigraphic traps and combination structuralstratigraphic traps also are likely to occur (see, for example, Houseknecht and Schenk, 2007).

\section{Charge}

Demonstrated source rocks that occur within the Arctic Alaska Fold-and-Thrust Belt AU include the Mississippian Kuna Formation in the upper part of the Lisburne Group, the Triassic Shublik Formation, the Jurassic lower Kingak Shale, the Triassic-Jurassic Otuk Formation, and the Lower Cretaceous pebble shale unit and GRZ (fig. 3). Regional seismic, well, and outcrop data and burial history modeling indicate that petroleum generation was controlled by sedimentary and tectonic burial. Initial hydrocarbon generation induced by sedimentation in the western Colville foredeep began about 120-110 Ma (fig. 6A) and progressed eastward and northward until about $90 \mathrm{Ma}$, with relatively modest additional generation occurring during the Late Cretaceous and Paleogene as the result of additional sedimentary burial and, near the mountain front, tectonic burial (Houseknecht and others, 2012b). This timing reflects the progressive filling of the foredeep and the broader foreland basin from southwest to northeast (Bird and Molenaar, 1992; Houseknecht and others, 2009a, b; Houseknecht and Bird, 2011). Migration pathways in this AU likely were controlled by stratal geometry (for example, clinoforms), unconformities, and faults. Geochemical evidence from oil-stained rocks in outcrop in this AU indicates widespread mixing of oil from two or more source rocks. In addition, gas generation in the foredeep during Tertiary structural burial and gas expansion related to Tertiary uplift likely caused remigration of some accumulated oil. Gas also may have been generated from thermal cracking of oil accumulations and from bitumen that did not migrate from source rocks during oil generation. Consideration of kerogen composition in the three major source-rock systems (fig. 4) and thermal maturity (figs. 5, 6A) indicates that the
AU is significantly gas-prone, although the potential for oil is demonstrated by the discovered Umiat accumulation, which is thought to have been sourced from the GRZ (Magoon and others, 2003).

\section{Rocks}

The dominant reservoirs in this AU are sandstone, although late Paleozoic carbonate reservoirs (Lisburne Group) also are viable, especially in thrust sheets close to the Brooks Range (Hanks and others, 1997). Oil and gas shows are common in this AU. The best known reservoir potential has been documented in Cretaceous and Tertiary fluvial-deltaic (topset) sandstone (Fortress Mountain, Nanushuk, Tuluvak, Schrader Bluff, and Sagavanirktok Formations) and coeval slope and basin-floor turbidite sandstone (Torok, Seabee, and Canning Formations; fig. 3). The largest known accumulations (Umiat oil accumulation and Gubik gas accumulation) occur in sandstone reservoirs of topset seismic facies in detachment anticline traps. Stratigraphic traps in both deep marine and shallow marine sandstone are likely (see, for example, Molenaar, 1988; Houseknecht and Schenk, 2007). There also is significant potential for low-permeability sandstone reservoirs, especially in association with overpressured gas accumulations (Nelson and others, 2006). Seals are provided by marine shale and mudstone.

\section{Timing and Preservation}

Oil generation began in the southern and western parts of the AU in the Early Cretaceous and progressed eastward and northward (Houseknecht and others, 2012b). Onshore, generation probably ended in late Eocene (about $45 \mathrm{Ma}$ ) but may be ongoing offshore in the eastern part of the AU where sedimentation and contractional deformation continue. An important consideration regarding charge in this AU is the inference that the fold-and-thrust belt formed as the result of two major phases of contractional deformation - one during the Early Cretaceous and the second during the Tertiary (Moore and others, 2004). Hydrocarbon generation modeling (Houseknecht and others, 2012b) suggests that - except for the eastern offshore part of the AU-most oil generation, primary migration, and initial accumulation in traps occurred during the Cretaceous, either contemporaneous with or immediately after the first major phase of deformation. Thus, the second phase of deformation occurred after oil accumulation in traps across much of the AU. The subsequent phase of deformation in the Tertiary may have disrupted traps and caused seal failure that may have resulted in remigration, and perhaps leakage to the surface, of oil and gas. In fact, it is likely that the Umiat oil accumulation, which is trapped in a structure that formed during the Paleogene (O'Sullivan, 1999) in an area where oil was generated during the early Cretaceous (Houseknecht and others, 2012b), is the result of remigration of oil from an older stratigraphic or combination trap (perhaps similar to that described by Houseknecht and Schenk, 2007) that failed during Paleogene deformation. In addition, gas generation during structural burial in the Colville foredeep and gas 
expansion related to uplift of parts of the fold-and-thrust belt during Paleogene deformation likely caused remigration of hydrocarbons that accumulated during generation and primary migration.

\section{Analogs Used for Assessment}

Assessment input was influenced by the geology, sizes, and numbers of discovered accumulations in the AU and by the assessments of undiscovered resources conducted by the USGS and MMS, which were largely based on the mapping of favorable trap geometries from 2-D seismic data. In those assessments, a total of 23 plays were identified and assessed within the area considered in the Arctic Alaska Fold-andThrust Belt AU. From those assessments, the mean value of undiscovered resources and number and sizes of undiscovered pools larger than $50 \mathrm{MMBOE}$ were tabulated and used as a consideration for completing the assessment input.

The USGS World Analog Database was used to help constrain assessment input parameters, especially the density of accumulations larger than $50 \mathrm{MMBOE}$ and the median and maximum sizes of accumulations. A search of compressional structural setting, plus continental crustal system, plus foreland architecture returned 43 potential analogs. These were culled to remove 16 AUs with transtensional and transpressional trap systems, extensional grabens and other structures related

Table 2. Analog assessment units used to constrain input parameters for the Arctic Alaska Fold-and-Thrust Belt Assessment Unit. Analog data from Charpentier and others (2008).

[AU, assessment unit; TPS, total petroleum system]

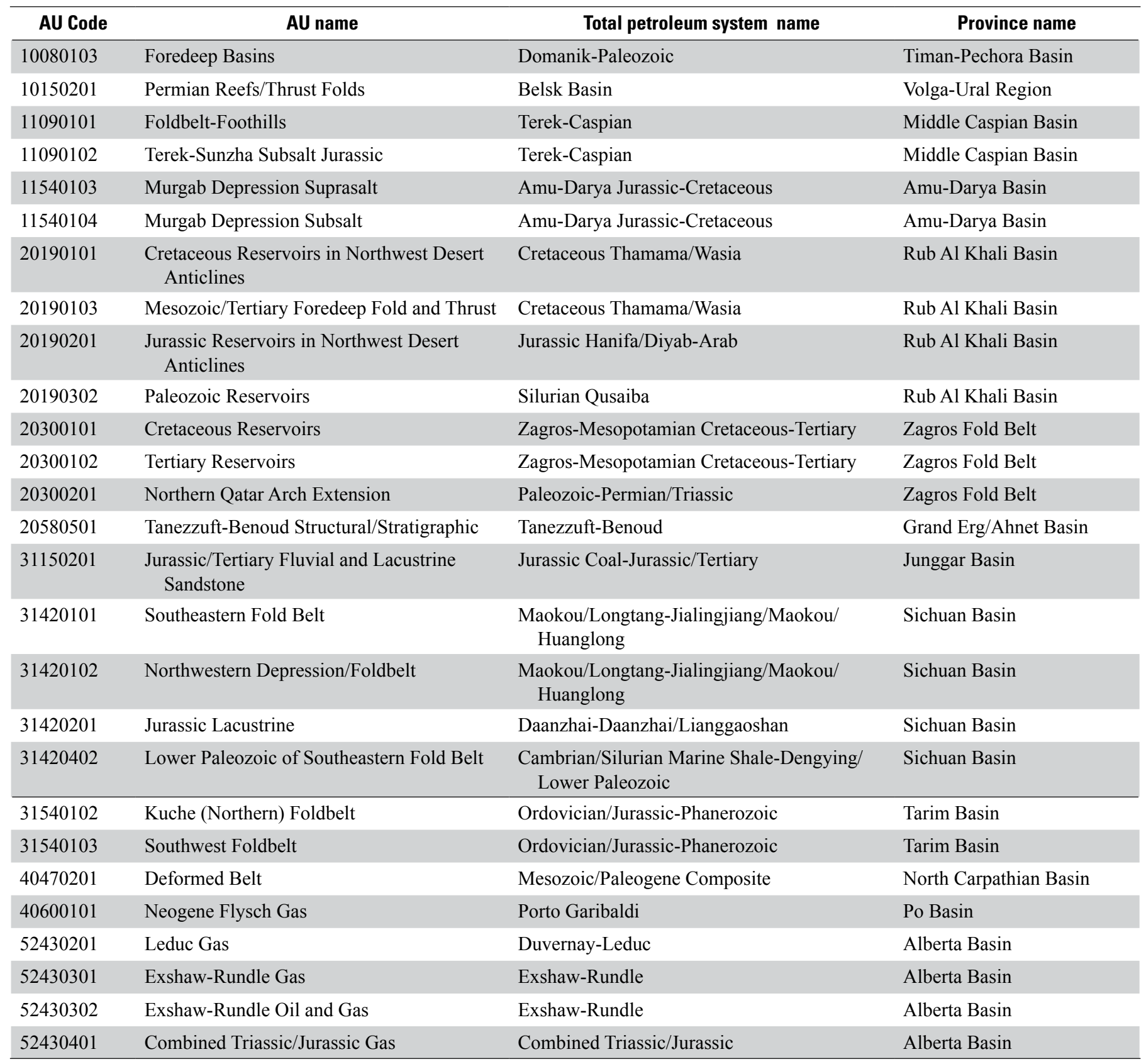


to normal faults, and salt-induced structures. The remaining 27 AUs (table 2) were considered as a population that may provide reasonable constraints on assessment input parameters.

\section{Assessment Inputs}

\section{Number of Accumulations}

Previous MMS and USGS assessments estimated 58 accumulations of at least $50 \mathrm{MMBOE}$ at the mean, which yields a density of 0.31 accumulations per $1,000 \mathrm{~km}^{2}$. With a focus on the previous assessments, a minimum of 10 to a maximum of 250 accumulations and a median value of 60 was used (appendix 2).

\section{Oil-to-Gas Mix}

The minimum, median, and maximum values for the oilto-gas ratio were set at $0.1,0.2$, and 0.3 (appendix 2) based on the ratio of oil/gas accumulations in the discovered population, empirical and modeled thermal maturity considerations, and the distribution of oil-versus gas-prone source rocks.

\section{Accumulation Size Distribution}

The median and maximum gas accumulation sizes were set at 700 and 14,000 BCF (appendix 2), based on the sizes of seismically mapped structural closures and known reservoir parameters. Inputs for oil accumulations sizes were scaled downward (median, $100 \mathrm{MMBO}$; maximum; 2,000 MMBO; ( appendix 2) relative to gas because of the poor timing for charging structural traps with oil and the overall gas-prone nature of the AU, primarily due to high levels of thermal maturity.

\section{Estimated Maximum Accumulation Size}

Maximum accumulation sizes of 5 TCFG and 400-500 MMBO were selected considering the sizes of seismically mapped structural closures, regional reservoir character, and sizes of discovered accumulations. These maximum sizes, which did not enter directly into the volumetric calculations, were used to judge the reasonableness of the results of statistical analysis.

Table 3. Summary of results for risked, undiscovered, technically recoverable petroleum resources for the Arctic Alaska Province.

[F95 represents a 95-percent chance of at least the amount tabulated; other fractiles are defined similarly. Std. dev., standard deviation]

\begin{tabular}{|c|c|c|c|c|c|}
\hline \multicolumn{3}{|c|}{ Assessment unit name } & \multicolumn{3}{|c|}{ Assessment unit probability } \\
\hline \multicolumn{3}{|l|}{ Platform } & \multicolumn{3}{|c|}{1.000} \\
\hline \multicolumn{3}{|l|}{ Fold-and-Thrust Belt } & \multicolumn{3}{|c|}{1.000} \\
\hline Assessment unit name & F95 & F50 & F5 & Mean & Std. dev. \\
\hline \multicolumn{6}{|c|}{ Oil, in millions of barrels (MMBO) } \\
\hline Platform & $13,866.70$ & $26,207.02$ & $47,425.71$ & $27,851.06$ & $10,450.85$ \\
\hline \multirow[t]{2}{*}{ Fold-and-Thrust Belt } & 587.64 & $1,761.86$ & $4,814.48$ & $2,109.89$ & $1,402.14$ \\
\hline & \multicolumn{5}{|c|}{ Associated/dissolved gas, in billions of cubic feet (BCF) } \\
\hline Platform & $17,176.27$ & $34,742.05$ & $68,535.20$ & $37,692.85$ & $16,215.51$ \\
\hline Fold-and-Thrust Belt & 640.54 & $2,255.62$ & $7,047.29$ & $2,846.06$ & $2,190.90$ \\
\hline \multicolumn{6}{|c|}{ Natural gas liquids, in millions of barrels (MMB) } \\
\hline Platform & 454.91 & 928.94 & $1,856.99$ & $1,011.71$ & 447.97 \\
\hline Fold-and-Thrust Belt & 16.51 & 59.86 & 191.90 & 76.42 & 60.64 \\
\hline \multicolumn{6}{|c|}{ Nonassociated gas, in billions of cubic feet (BCFG) } \\
\hline Platform & $53,122.97$ & $112,562.12$ & $222,711.73$ & $121,860.59$ & $53,452.97$ \\
\hline Fold-and-Thrust Belt & $24,272.55$ & $52,465.41$ & $115,798.60$ & $58,998.09$ & $29,620.91$ \\
\hline \multicolumn{6}{|c|}{ Liquids, in millions of barrels (MMB) } \\
\hline Platform & $1,391.94$ & $2,993.27$ & $5,989.52$ & $3,245.45$ & $1,449.80$ \\
\hline Fold-and-Thrust Belt & 640.60 & $1,395.64$ & $3,107.19$ & $1,571.39$ & 795.92 \\
\hline \multicolumn{6}{|c|}{ Largest oil, in millions of barrels (MMB) } \\
\hline Platform & $1,264.08$ & $2,904.98$ & $6,603.05$ & $3,280.92$ & $1,619.33$ \\
\hline Fold-and-Thrust Belt & 150.55 & 384.26 & $1,138.93$ & 476.29 & 318.23 \\
\hline \multicolumn{6}{|c|}{ Largest nonassociated gas, in billions of cubic feet (BCF) } \\
\hline Platform & $6,136.18$ & $15,403.31$ & $38,866.11$ & $17,864.13$ & $9,928.09$ \\
\hline Fold-and-Thrust Belt & $2,475.42$ & $5,194.98$ & $11,160.75$ & $5,763.17$ & $2,617.91$ \\
\hline
\end{tabular}




\section{Ancillary Properties and Co-Product Ratios}

Data from discovered pools in this AU and from geochemistry of source rocks were used to establish input values for these parameters.

\section{Results}

Probabilistic estimates of volumes of undiscovered, technically recoverable hydrocarbons for the Arctic Alaska Fold-and-Thrust Belt AU are summarized in table 3. These results include mean estimates of $2 \mathrm{BBO}$, nearly $3 \mathrm{TCF}$ associated gas, and $59 \mathrm{TCF}$ nonassociated gas.

\section{Summary and Conclusions}

The Arctic Alaska Province is part of a displaced continental fragment, the Arctic Alaska microplate, which rifted from the Canada Arctic margin during opening of the Canada Basin. Petroleum-prospective rocks in the province, mostly Mississippian and younger, record a sequential geologic evolution through passive margin, rift, and foreland basin tectonic stages. Significant petroleum source and reservoir rocks were formed during each tectonic stage, but it was the foreland basin stage that provided sufficient burial for widespread hydrocarbon generation.

Three major source-rock systems (Triassic, Jurassic, and Cretaceous-Paleogene) contribute to the overall richness of the province, although details of regional source-rock quality remain poorly known because of limited data. Relative to levels of thermal maturity appropriate for the generation and preservation of oil, these source rocks grade northward from overmature in the Colville foredeep to early mature to immature on the rift shoulder. Burial history and hydrocarbon generation modeling indicates that peak oil generation occurred mostly during the Cretaceous in the foredeep. Thermal maturity abruptly grades northward from immature to mature, and even overmature, along the northernmost margin of the province where strata thicken into the Amerasia Basin Province. Although it is unlikely that the Triassic and Jurassic source rocks are present beyond the hingeline because the Amerasia Basin was not yet open at the time of deposition, oil generated in younger source rocks may have migrated southward into the Arctic Alaska Province during Cretaceous through Paleogene generation.

The majority of known petroleum resources in the province occur in combination structural-stratigraphic traps formed as a consequence of rifting and located along the rift shoulder. Most exploration activity in the province has been focused on either combination or structural traps, although oil discoveries during the past 20 years have increased the emphasis on stratigraphic traps.

The Arctic Alaska Province was divided into two AUs for appraisal of undiscovered petroleum resources in conventional accumulations. The platform AU includes the Alaska rift shoulder and its relatively undeformed flanks, and the fold-and-thrust belt AU includes the deformed areas north of the Brooks Range and Herald Arch tectonic belts.

The Arctic Alaska Platform AU includes at least 15 oil and 2 gas accumulations larger than $50 \mathrm{MMBOE}$, including the largest oil field in North America at Prudhoe Bay. Considering that a relatively small proportion of the AU has been explored, the potential for discovery of additional accumulations is considered high. Mean estimates for undiscovered, technically recoverable resources in conventional accumulations include nearly $28 \mathrm{BBO}$, more than 37 TCF of associated gas, and more than 120 TCF of nonassociated gas.

The Arctic Alaska Fold-and-Thrust Belt AU is lightly explored and includes multiple oil and gas discoveries, including at least one oil and one gas accumulation that exceed the 50-MMBOE threshold for the CARA. Exploration in this AU has been limited by the absence of a market for natural gas and the perception that it is a gas-prone region. The potential for discovery of additional accumulations is considered high. Mean estimates for undiscovered, technically recoverable resources in conventional accumulations include $2 \mathrm{BBO}$, nearly $3 \mathrm{TCF}$ of associated gas, and $59 \mathrm{TCF}$ of nonassociated gas.

\section{Acknowledgments}

This report was improved as the result of constructive reviews by Kirk Sherwood (U.S. Department of the Interior, Bureau of Ocean Energy Management), Margaret Keller, and Jim Coleman.

\section{References Cited}
Alaska Division of Oil and Gas, 2007, Alaska oil and gas report, July 2007: Accessed December 5, 2011, at http://dog. dnr.alaska.gov/Publications/AnnualReports.htm.

ANWR Assessment Team, 1999, The oil and gas resource potential of the Arctic National Wildlife Refuge 1002 area, Alaska: U.S. Geological Survey Open-File Report 98-34, accessed December 5, 2011, at http://pubs.usgs.gov/of/1998/ ofr-98-0034/.

Balkwill, H.R., Cook, D.G., Detterman, R.L., Embry, A.F., Hakansson, E., Miall, A.D., Poulton, T.P. and Young, F.G., 1983, Arctic North America and northern Greenland, in Moullade, M., and Nairn, A.E.M., eds., The Phanerozoic geology of the world II; the Mesozoic, B: Elsevier, Amsterdam, p. 1-31.

Bird, K.J., 1985, The framework geology of the North Slope of Alaska as related to oil-source rock correlations, in Magoon, L.B., and Claypool, G.E., eds., Alaska North Slope oil/ rock correlation study: American Association of Petroleum Geologists, Studies in Geology 20, p. 3-29. 
Bird, K.J., 1988, Structure-contour and isopach maps of the National Petroleum Reserve in Alaska, in Gryc, G., ed., Geology and exploration of the National Petroleum Reserve in Alaska, 1974 to 1982: U.S. Geological Survey Professional Paper 1399, p. 355-377.

Bird, K.J., 2001, Alaska-A twenty-first-century petroleum province, in Downey, M.W., Threet, J.C., and Morgan, W.A., eds., Petroleum provinces of the twenty-first century: American Association of Petroleum Geologists Memoir 74, p. 137-165.

Bird, K.J., and Bader, J.W., 1987, Regional geologic setting and history of petroleum exploration, in Bird, K.J., and Magoon, L.B., eds., Petroleum geology of the northern part of the Arctic National Wildlife Refuge, northeastern Alaska:U.S. Geological Survey Bulletin 1778, p. 17-25.

Bird, K.J., Charpentier, R.R., Gautier, D.L., Houseknecht, D.W., Klett, T.R., Pitman, J.K., Moore, T.E., Schenk, C.J., Tennyson, M.E., and Wandrey, C.R., 2008, Circum-Arctic Resource Appraisal-Estimates of undiscovered oil and gas north of the Arctic Circle: U.S. Geological Survey Fact Sheet 2008-3049, 4 p., accessed December 5, 2011, at http:/pubs.usgs.gov/fs/2008/3049/.

Bird, K.J., and Houseknecht, D.W., 2011, Geology and petroleum potential of Arctic Alaska, in Spencer, A.M., Embry, A.F., Gautier, D.L., Stoupakova, A.V., and Sørensen, K., eds., Arctic petroleum geology: Geological Society of London Memoir 35, p. 485-499.

Bird, K.J., Houseknecht, D.W., Attanasi, E.D., Moore, T.E., Nelson, P.H., Potter, C.J., Schenk, C.J., Schuenemeyer, J.H., Verma, M.K., Saltus, R.W., Phillips, J.D., Charpentier, R.R., Cook, T.A., Klett, T.R., and Pollastro, R.M., 2005, Oil and gas assessment of central North Slope, Alaska, 2005: U.S. Geological Survey Fact Sheet 2005-3043, 2 p., accessed December 5, 2011, at http://pubs.usgs.gov/ fs $/ 2005 / 3043 /$.

Bird, K.J., and Molenaar, C.M., 1992, The North Slope foreland basin, Alaska, in Macqueen R.W., and Leckie, D.A., eds., Foreland basins and foldbelts: American Association of Petroleum Geologists Memoir 55, p. 363-393.

Burnham, A.K., and Sweeney, J.J., 1989, A chemical kinetic model of vitrinite maturation and reflectance: Geochimica et Cosmochimica Acta, v. 53, p. 2649-2657.

Burns, W.M., Hayba, D.O., Rowan, E.L., and Houseknecht, D.W., 2007, Estimating the amount of eroded section in a partially exhumed basin using geophysical logs-An example from the Alaska North Slope: U.S. Geological Survey Professional Paper 1732-D, 18 p., accessed December 5, 2011, at http://pubs.usgs.gov/pp/pp1732/ pp $1732 \mathrm{~d} /$.

Carman, G.J., and Hardwick, P., 1983, Geology and regional setting of Kuparuk oil field, Alaska: American Association of Petroleum Geologists Bulletin, v. 67, p. 1014-1031.
Charpentier, R.R., 2017, Methodology for assessment of undiscovered oil and gas resources for the 2008 CircumArctic Resource Appraisal, chap. B of Moore, T.L., and Gautier, D.L., eds., The 2008 Circum-Arctic Resource Appraisal: U.S. Geological Survey Professional Paper 1824, 7 p., https://doi.org/10.3133/pp1824b.

Charpentier, R.R., and Gautier, D.L., 2011, U.S. Geological Survey Circum-Arctic Resource Appraisal (CARA) Introduction and summary of organization and methods, in Spencer, A.M., Embry, A.F., Gautier, D.L., Stoupakova, A.V., and Sørensen, K., eds., Arctic petroleum geology: Geological Society of London Memoir 35, p. 145-150.

Charpentier, R.R., Klett, T.R., and Attanasi, E.D., 2008, Database for assessment unit-scale analogs (exclusive of the United States): U.S. Geological Survey Open-File Report 2007-1404, 61 p., accessed December 5, 2011, at http:// pubs.usgs.gov/of/2007/1404/.

Claypool, G.E., and Magoon, L.B., 1985, Comparison of oil-source rock correlation data for Alaskan North SlopeTechniques, results, and conclusions, in Magoon, L.B., and Claypool, G.E., eds., Alaska North Slope oil/rock correlation study: American Association of Petroleum Geologists, Studies in Geology 20, p. 49-81.

Craig, J.D., and Sherwood, K.W., 2004, Economic study of the Burger gas discovery, Chukchi shelf, northwest Alaska: Minerals Management Service, 71 p., accessed December 5, 2011, at http:/www.mms.gov/alaska/re/BurgerResources/ Economic\%20Study\%20of\%20the\%20Burger\%20Gas\%20 Discovery.pdf.

Creaney, S., and Passey, Q.R., 1993, Recurring patterns of total organic carbon and source rock quality within a sequence stratigraphic framework: American Association of Petroleum Geologists Bulletin, v. 77, p. 386-401.

Crowder, R.K., 1990, Permian and Triassic sedimentation in the northeastern Brooks Range, Alaska-Deposition of the Sadlerochit Group: American Association of Petroleum Geologists Bulletin, v. 74, p. 1351-1370.

Dietrich, J.R., and Lane, L.S., 1992, Geology and structural evolution of the Demarcation subbasin and Herschel high, Beaufort-Mackenzie basin, Arctic Canada: Bulletin of Canadian Petroleum Geology, v. 40, p. 188-197.

Dow, W.G., 1998, Organic geochemistry of Cretaceous, Jurassic, and Triassic shales from the northwestern DeLong Mountains, western Brooks Range, Alaska, 1994-1997: Alaska Division of Geological \& Geophysical Surveys Public Data File 98-35, 181 p., accessed December 5, 2011, at http://www.dggs.dnr.state.ak.us/webpubs/dggs/pdf/text/ pdf1998_035.PDF. 
Dow, W.G., and Talukdar, S.C., 1995, Geochemical analysis of outcrop samples, northwestern De Long Mountains, Brooks Range, Alaska: Alaska Division of Geological \& Geophysical Surveys Public Data File 95-29, 43 p., accessed December 5, 2011, at http://www.dggs.dnr.state. ak.us/webpubs/dggs/pdf/text/pdf1995_029.PDF.

Dumoulin, J.A., 2001, Lithologies of the basement complex (Devonian and older) in the National Petroleum Reserve-Alaska, in Houseknecht, D.W., ed., NPRA Core Workshop-Petroleum Plays and Systems in the National Petroleum Reserve-Alaska: Society for Sedimentary Geology (SEPM) Core Workshop 21, p. 201-214.

Dumoulin, J.A., Burruss, R.C., and Lillis, P.G., 2008a, Lisburne petroleum system, in Kelley, K.D., ed., Regional fluid flow and basin modeling in northern Alaska: U.S. Geological Survey Circular 1319, p. 36-40, accessed December 5, 2011, at http://pubs.usgs.gov/circ/1319/.

Dumoulin, J.A., Slack, J.F., Whalen, M.T., and Harris, A.G., 2011, Depositional setting and geochemistry of phosphorites and metalliferous black shales in the CarboniferousPermian Lisburne Group, northern Alaska, in Dumoulin, J.A., and Galloway, J.P., eds., Studies by the U.S. Geological Survey in Alaska, 2008-2009: U.S. Geological Survey Professional Paper 1776-C, 64 p., accessed December 5, 2011, at http://pubs.usgs.gov/pp/1776/c/.

Dumoulin, J.A., Whalen, M.T., and Harris, A.G., 2008b, Lithofacies, age, and sequence stratigraphy of the Carboniferous Lisburne Group in the Skimo Creek area, central Brooks Range, in Haeussler, P.J., and Galloway, J.P., eds., Studies by the U.S. Geological Survey in Alaska, 2006: U.S. Geological Survey Professional Paper 1739-B, 64 p., accessed December 5, 2011, at http://pubs.usgs.gov/ $\mathrm{pp} / \mathrm{pp} 1739 / \mathrm{b} /$.

Embry, A.F., 1990, Geological and geophysical evidence in support of the hypothesis of anticlockwise rotation of northern Alaska: Marine Geology, v. 93, p. 317-329.

Embry, A.F., 2000, Counterclockwise rotation of the Arctic Alaska plate-Best available model or untenable hypothesis for the opening of the Amerasia basin: Polarforschung, v. 68 , p. $247-255$.

Gautier, D.L., Bird, K.J., Charpentier, R.R., Grantz, A., Houseknecht, D.W., Klett, T.R., Moore, T.E., Pitman, J.K., Schenk, C.J., Schuenemeyer, J.H., Sørensen, K., Tennyson, M.E., Valin, Z.C., and Wandrey, C.J., 2009, Assessment of undiscovered oil and gas in the Arctic: Science, v. 324, p. $1175-1179$.

Gautier, D.L., Bird, K.J., Charpentier, R.R., Grantz, A., Houseknecht, D.W., Klett, T.R., Moore, T.E., Pitman, J.K., Schenk, C.J., Schuenemeyer, J.H., Sørensen, K., Tennyson, M.E., Valin, Z.C., and Wandrey, C.J., 2011a, Oil and gas resource potential north of the Arctic Circle, in Spencer, A.M., Embry, A.F., Gautier, D.L., Stoupakova, A.V., and Sørensen, K., eds., Arctic petroleum geology: Geological Society of London Memoir 35, p. 151-161.
Gautier, D.L., Stemmerik, L., Christiansen, F.G., Sørensen, K., Bidstrup, T., Bojesen-Koefoed, J.A., Bird, K.J., Charpentier, R.R., Houseknecht, D.W., Klett, T.R., Schenk, C.J., and Tennyson, M.E., 2011b, Assessment of northeast Greenland-Prototype for development of Circum-Arctic Resource Appraisal methodology, in Spencer, A.M., Embry, A.F., Gautier, D.L., Stoupakova, A.V., and Sørensen, K., eds., Arctic petroleum geology: Geological Society of London Memoir 35, p. 663-672.

Gingrich, D., Knock, D., and Masters, R., 2001, Geophysical interpretation methods applied at Alpine oil field, North Slope, Alaska: Leading Edge, v. 20, no. 7, p.730-738.

Gradstein, F.M., Ogg, J.G., Smith, A.G., Bleeker, W., and Lourens, L.J., 2004, A new geologic time scale, with special reference to Precambrian and Neogene: Episodes, v. 27, p. 83-100.

Grantz, A., Hart, P.E., and Childers, V.A., 2011, Geology and tectonic development of the Amerasia and Canada basins, Arctic Ocean, in Spencer, A.M., Embry, A.F., Gautier, D.L., Stoupakova, A.V., and Sørensen, K., eds., Arctic petroleum geology: Geological Society of London Memoir 35, p. 771-799.

Grantz, A., and May, S.D., 1982, Rifting history and structural development of the continental margin north of Alaska, in Watkins, J.S., and Drake, C.L., eds., Studies in continental margin geology: American Association of Petroleum Geologists Memoir 34, p. 77-100.

Grantz, A., and May, S.D., 1988, Regional geology and petroleum potential of the United States Chukchi shelf north of Point Hope, in Gryc, G., ed., Geology and exploration of the National Petroleum Reserve in Alaska, 1974 to 1982: U.S. Geological Survey Professional Paper 1399, p. 209-230.

Grantz, A., May, S.D., and Hart, P.E., 1990, Geology of the Arctic continental margin of Alaska, in Grantz, A., Johnson, G.L., and Sweeney, J.F., eds., The Arctic Ocean region: Boulder, Colo., Geological Society of America, The Geology of North America, v. L, p. 257-288.

Hanks, C.L., Lorenz, J., Teufel, L., and Krumhardt, A.P., 1997, Lithologic and structural controls on natural fracture distribution and behavior within the Lisburne Group, northeastern Brooks Range and North Slope subsurface, Alaska: American Association of Petroleum Geologists Bulletin, v. 81, p.1700-1720.

Hohler, J.J., and Bischoff, W.E., 1986, Alaska-Potential for giant fields, in Halbouty, M.T., ed., Future petroleum provinces of the world: American Association of Petroleum Geologists Memoir 40, p. 131-142.

Houseknecht, D.W., and Bird, K.J., 2004, Sequence stratigraphy of the Kingak Shale (Jurassic-Lower Cretaceous), National Petroleum Reserve in Alaska: American Association of Petroleum Geologists Bulletin, v. 88, p. 279-302. 
Houseknecht, D.W., and Bird, K.J., 2006, Oil and gas resources of the Arctic Alaska Petroleum Province: U.S. Geological Survey Professional Paper 1732-A, 11 p., accessed December 5, 2011, at http://pubs.usgs.gov/pp/ pp1732/pp1732a/.

Houseknecht, D.W., and Bird, K.J., 2011, Geology and petroleum potential of the rifted margins of the Canada basin, in Spencer, A.M., Embry, A.F., Gautier, D.L., Stoupakova, A.V., and Sørensen, K., eds., Arctic petroleum geology: Geological Society of London Memoir 35, p. 509-526.

Houseknecht, D.W., Bird, K.J., and Garrity, C.P., 2012a, Assessment of undiscovered petroleum resources of the Amerasia Basin petroleum province: U.S. Geological Survey Scientific Investigations Report 2012-5146, 36 p.

Houseknecht, D.W., Bird, K.J., and O'Sullivan, P., 2011, Constraining the age and magnitude of uplift in the northern National Petroleum Reserve in Alaska (NPRA) - Apatite fission-track analysis of samples from three wells, in Dumoulin, J.A., and Dusel-Bacon, C., eds., Studies by the U.S. Geological Survey in Alaska, 2010: U.S. Geological Survey Professional Paper 1784-A, 21 p., 1 pl., accessed December 5, 2011, at http://pubs.usgs.gov/pp/1784/a/.

Houseknecht, D.W., Bird, K.J., and Schenk, C.J., 2009a, Seismic analysis of clinoform depositional sequences and shelf-margin trajectories in Cretaceous (Albian) strata, Alaska North Slope: Basin Research, v. 21, p. 644-654.

Houseknecht, D.W., Burns, W.M., and Bird, K.J., 2012b, Thermal maturation history of Arctic Alaska and southern Canada basin, in Harris, N.B., and Peters, K.E., eds., Thermal history analysis of sedimentary basins - methods and case histories: Society for Sedimentary Geology Special Publication 103, p. 199-219.

Houseknecht, D.W., LePain, D.L., Decker, P.L., and Schenk, C.J., 2009b, Lower Cretaceous clinoforms in Arctic Alaska-Core workshop: American Association of Petroleum Geologists and Alaska Geological Society, Core Workshop Notes from 2009 AAPG Annual Meeting, Denver, Colo., 91 p.

Houseknecht, D.W., Bird, K.J., Schuenemeyer, J.H., Attanasi, E.D., Garrity, C.P., Schenk, C.J., Charpentier, R.R., Pollastro, R.M., Cook, T.A., and Klett, T.R., 2010, 2010 updated assessment of undiscovered oil and gas resources of the National Petroleum Reserve in Alaska (NPRA): U.S. Geological Survey Fact Sheet 2010-3102, 4 p., accessed December 5, 2011, at http://pubs.usgs.gov/fs/2010/3102/.

Houseknecht, D.W., and Schenk, C.J., 2007, Outcrops of turbidite channel facies in the Torok Formation-Reservoir analogs for the Alaska North Slope, in Nilsen, T., Shew, R.D., Steffens, G.S., and Studlick, J.R.J., eds., An atlas of deepwater outcrops-Models and analogs: American Association of Petroleum Geologists, Studies in Geology 56, p. 373-377.
Hubbard, R.J., Edrich, S.P., and Rattey, R.P., 1987, Geologic evolution and hydrocarbon habitat of the "Arctic Alaska microplate": Marine and Petroleum Geology, v. 4, p. 2-34.

Hudson, T.L., Nelson, P.H., Bird, K.J., and Huckabay, A., 2006, Exploration history (1964-2000) of the Colville high, North Slope, Alaska: Alaska Geological Survey, Miscellaneous Publication 136, $31 \mathrm{p}$.

Jameson, J., 1994, Models of porosity formation and their impact on reservoir description, Lisburne field, Prudhoe Bay, Alaska: American Association of Petroleum Geologists Bulletin, v. 78, p. 1651-1678.

Jamison, H.C., Brockett, L.D., and MacIntosh, R.A., 1980, Prudhoe Bay-A 10-year perspective, in Halbouty, M.T., ed., Giant oil and gas fields of the decade 1968-1978: American Association of Petroleum Geologists Memoir 30, p. 289-314.

Johnsson, M.J., Howell, D.G., and Bird, K.J., 1993, Thermal maturity patterns in Alaska-Implications for tectonic evolution and hydrocarbon potential: American Association of Petroleum Geologists Bulletin, v. 77, p. 1874-1903.

Johnston, D., 2007, Prospectivity and hydrocarbon potential of the Mackenzie delta-Beaufort Sea petroleum province-A northern Gulf of Mexico waiting for its time [abs.]: Canadian Society of Petroleum Geologists, Gussow Conference abstract and online video, accessed December 5, 2011, at http://www.cspg.org/conventions/abstracts/2007abstracts_ gussow.htm.

Jones, H.P., and Speers, R.G., 1976, Permo-Triassic reservoirs of Prudhoe Bay field, North Slope, Alaska, in Braunstein, Jules, ed., North American oil and gas fields: American Association of Petroleum Geologists Memoir 24, p. 23-50.

Klett, T.R., and Pitman, J.K., 2011, Geology and petroleum potential of the East Barents Sea basins and Admiralty arch, in Spencer, A.M., Embry, A.F., Gautier, D.L., Stoupakova, A.V., and Sørensen, K., eds., Arctic petroleum geology: Geological Society of London Memoir 35, p. 295-310.

Klett, T.R., Wandrey, C.J., and Pitman, J.K., 2011, Geology and petroleum potential of the north and east margins of the Siberian craton, in Spencer, A.M., Embry, A.F., Gautier, D.L., Stoupakova, A.V., and Sørensen, K., eds., Arctic petroleum geology: Geological Society of London Memoir 35, p. 413-431.

Kupecz, J.A., 1995, Depositional setting, sequence stratigraphy, diagenesis, and reservoir potential of a mixedlithology, upwelling deposit-The Upper Triassic Shublik Formation, Prudhoe Bay, Alaska: American Association of Petroleum Geologists Bulletin, v. 79, p. 1301-1319.

Lane, L.S., 1997, Canada basin, Arctic Ocean-Evidence against a rotational origin: Tectonics, v. 16, p.363-387.

Lawver, L.A., and Scotese, C.R., 1990, A review of tectonic models for the evolution of the Canada basin, in Grantz, A., Johnson, G.L., and Sweeney, J.F., eds., The Arctic Ocean region: Boulder, Colo., Geological Society of America, The Geology of North America, v. L, p. 593-618. 
Lawver, L.A., Grantz, A., and Gahagan, L.M., 2002, Plate kinematic evolution of the present Arctic region since the Ordovician, in Miller, E.L., Grantz, A., and Klemperer, S.L., eds., Tectonic evolution of the Bering shelf-Chukchi SeaArctic margin and adjacent landmasses: Geological Society of America Special Paper 360, p. 333-358.

Lawver, L.A., Gahagan, L.M., and Norton, I., 2011, Palaeogeographic and tectonic evolution of the Arctic region during the Palaeozoic, in Spencer, A.M., Embry, A.F., Gautier, D.L., Stoupakova, A.V., and Sørensen, K., eds., Arctic petroleum geology: Geological Society of London Memoir 35, p. 61-77.

Lerand, M., 1973, Beaufort Sea, in McCrossan, R.G., ed., The future petroleum provinces of Canada-Their geology and potential: Canadian Society of Petroleum Geologists Memoir 1, p. 315-386.

Lillis, P.G., Lewan, M.D., Warden, Augusta, Monk, S.M., and King, J.D., 1999, Identification and characterization of oil types and their source rocks, in U.S. Geological Survey, ANWR Assessment Team, The oil and gas resource potential of the Arctic National Wildlife Refuge 1002 area, Alaska: U.S. Geological Survey Open-File Report 98-34, 101 p., accessed December 5, 2011, at http://energy.cr.usgs. gov/OF98-34/OA.pdf.

Macquaker, J.H.S., and Keller, M.A., 2005, Mudstone sedimentation at high latitudes-Ice as a transport medium for mud and supplier of nutrients: Journal of Sedimentary Research, v. 75, p. 696-709.

Magoon, L.B., 1994, The geology of known oil and gas resources by petroleum system-Onshore Alaska, in Plafker, G., and Berg, H.C., eds., The geology of Alaska: Geological Society of America, The Geology of North America, v. G-1, p. 905-936.

Magoon, L.B., and Bird, K.J., 1988, Evaluation of petroleum source rocks in the National Petroleum Reserve in Alaska, using organic-carbon content, hydrocarbon content, visual kerogen, and vitrinite reflectance, in Gryc, G., ed., Geology and exploration of the National Petroleum Reserve in Alaska, 1974 to 1982: U.S. Geological Survey Professional Paper 1399, p. 381-450.

Magoon, L.B., Bird, K.J., Burruss, R.C., Hayba, D., Houseknecht, D.W., Keller, M.A., Lillis, P.G., and Rowan, E.L., 1999, Evaluation of hydrocarbon charge and timing using the petroleum system, in ANWR Assessment Team, The oil and gas resource potential of the Arctic National Wildlife Refuge 1002 area, Alaska: U.S. Geological Survey OpenFile Report 98-34, 66 p., accessed December 5, 2011, at http://energy.cr.usgs.gov/OF98-34/PS.pdf.

Magoon, L.B., and Claypool, G.E., eds., 1985, Alaska North Slope oil/source rock correlation study: American Association of Petroleum Geologists, Studies in Geology $20,685 \mathrm{p}$.
Magoon, L.B., Lillis, P.G., Bird, K.J., Lampe, C., and Peters, K.E., 2003, Alaskan North Slope petroleum systems: U.S. Geological Survey Open-File Report 03-324, 3 sheets, accessed December 5, 2011, at http://geopubs.wr.usgs.gov/ open-file/of03-324/.

Magoon, L.B., Woodward, P.V., Banet, A.C., Jr., Griscom, S.B., and Daws, T.A., 1987, Thermal maturity, richness, and type of organic matter of source-rock units, in Bird, K.J., and Magoon, L.B., eds., Petroleum geology of the northern part of the Arctic National Wildlife Refuge, northeastern Alaska: U.S. Geological Survey Bulletin 1778, p. 127-179.

Masterson, W.D., IV, 2001, Petroleum filling history of central Alaskan North Slope fields: University of Texas at Dallas, Ph.D. dissertation, $222 \mathrm{p}$.

Masterson, W.D., and Eggert, J.T., 1992, Kuparuk River field, North Slope, Alaska, in Beaumont, E.A., and Foster, N.H., eds., Stratigraphic traps III: American Association of Petroleum Geologists Treatise of Petroleum Geology, Atlas of Oil and Gas Fields, p. 257-284.

Masterson,W.D., and Paris, C.E., 1987, Depositional history and reservoir description of the Kuparuk River Formation, North Slope, Alaska, in Tailleur, I., and Weimer, P., eds., Alaskan North Slope geology: Pacific Section Society of Economic Palentologists and Mineralogists (SEPM) and Alaska Geological Society, p. 95-107.

Melvin, J., and Knight, A.S., 1984, Lithofacies, diagenesis and porosity of the Ivishak Formation, Prudhoe Bay area, Alaska, in McDonald, D.A., and Surdam, R.C., eds., Clastic diagenesis: American Association of Petroleum Geologists Memoir 37, p. 347-365.

Minerals Management Service, 2006, Undiscovered oil and gasresources, Alaska Federal off shoreas of 2006: Accessed December 5, 2011, at http://www.mms.gov/alaska/re/ reports/2006Asmt/index.HTM.

Molenaar, C.M., 1982, Umiat field, an oil accumulation in a thrust-faulted anticline, North Slope of Alaska, in Powers, R.B., ed., Geologic studies of the Cordilleran thrust belt: Rocky Mountain Association of Geologists, p. 537-548.

Molenaar, C.M., 1983, Depositional relations of Cretaceous and Lower Tertiary rocks, northeastern Alaska: American Association of Petroleum Geologists Bulletin, v. 67, p. 1066-1080.

Molenaar, C.M., 1988, Depositional history and seismic stratigraphy of Lower Cretaceous rocks in the National Petroleum Reserve in Alaska and adjacent areas, in Gryc, G., ed., Geology and exploration of the National Petroleum Reserve in Alaska, 1974 to 1982: U.S. Geological Survey Professional Paper 1399, p. 593-620. 
Moore, T.E., Dumitru, T.A., Adams, K.E., Witebsky, S.N., and Harris,A.G., 2002, Origin of the Lisburne Hills-Herald Arch structural belt-Stratigraphic, structural, and fissiontrack evidence from the Cape Lisburne area, northwestern Alaska, in Miller, E.L., Grantz, A., and Klemperer, S.L., eds., Tectonic evolution of the Bering Shelf-Chukchi SeaArctic Margin and adjacent landmasses: Geological Society of America Special Paper 360, p. 77-109.

Moore, T.E., Grantz, A., Pitman, J.K., and Brown, P.J., 2011, A first look at the petroleum geology of the Lomonosov Ridge microcontinent, Arctic Ocean, in Spencer, A.M., Embry, A.F., Gautier, D.L., Stoupakova,A.V., and Sørensen, K., eds., Arctic Petroleum Geology: Geological Society of London Memoir 35, p.751-769.

Moore, T.E., and Pitman, J.K., 2011, Geology and petroleum potential of the Eurasia Basin, in Spencer, A.M., Embry, A.F., Gautier, D.L., Stoupakova, A.V., and Sørensen, K., eds., Arctic petroleum geology: Geological Society of London Memoir 35, p. 731-750.

Moore, T.E., Potter, C.J., O'Sullivan, P.B., Shelton, K.L., and Underwood, M.B., 2004, Two stages of deformation and fluid migration in the west-central Brooks Range fold and thrust belt, northern Alaska, in Swennen, R., Roure, F., and Granath, J.W., eds., Deformation, fluid flow, and reservoir appraisal in foreland fold and thrust belts: American Association of Petroleum Geologists Hedberg Series, no. 1, p. 157-186.

Moore, T.E., Wallace, W.K., Bird, K.J., Karl, S.M., Mull, C.G., and Dillon, J.T., 1994, Geology of northern Alaska, in Plafker, G., and Berg, H.C., eds., The geology of Alaska: Boulder, Colo., Geological Society of America, The Geology of North America, v. G-1, p.49-140.

Mull, C.G., 2000, Summary report on the geology and hydrocarbon potential of the foothills of the northwestern DeLong Mountains, western Brooks Range, Alaska: Alaska Division of Geological and Geophysical Surveys, Preliminary Interpretive Report 2000-9, 12 p., accessed December 5, 2011, at http://www.dggs.dnr.state.ak.us/ webpubs/dggs/pir/text/pir2000_009.PDF.

Mull, C.G., Houseknecht, D.W., and Bird, K.J., 2003, Revised Cretaceous and Tertiary stratigraphic nomenclature in the east-central Colville basin, northern Alaska: U.S. Geological Survey Professional Paper 1673, 51 p., accessed December 5, 2011, at http://pubs.usgs.gov/pp/p1673/p1673.pdf.

Mull, C.G., Tailleur, I.L., Mayfield, C.F., Ellersieck, I., and Curtis, S.M., 1982, New upper Paleozoic and lower Mesozoic stratigraphic units, central and western Brooks Range, Alaska: American Association of Petroleum Geologists Bulletin, v. 66, p.348-362.
Nelson, P.H., Bird, K.J., Houseknecht, D.W., Potter, C.J., and Moore, T.E., 2006, Potential tight gas resources in a frontier province-Jurassic through Tertiary strata beneath the Brooks Range foothills, Arctic Alaska: U.S. Geological Survey Open-File Report 2006-1172, 2 sheets, accessed December 5, 2011, at http://pubs.usgs.gov/of/2006/1172/.

Oldow, J.S., Seidensticker, C.M., Phelps, J.C., Julian, F.E., Gottschalk, R.R., Boler, K.W., Handschy, J.W., and Avé Lallemant, H.G., 1987, Balanced cross sections through the central Brooks Range and North Slope, Arctic Alaska: American Association of Petroleum Geologists Publication, 19 p., 8 pl., scale 1:200,000.

Osadetz, K.G., Dixon, James, Dietrich, J.R., Snowdon, L.R., Dallimore, S.R., and Majorowicz, J.A., 2005, A review of Mackenzie Delta-Beaufort Sea petroleum province conventional and non-conventional (gas hydrate) petroleum reserves and undiscovered resources-A contribution to the resource assessment of the proposed Mackenzie DeltaBeaufort Sea marine protected areas: Geological Survey of Canada, Open File 4828, 31 p. plus figures and appendixes.

O'Sullivan, P.B., 1999, Thermochronology, denudation and variations in paleosurface temperature-A case study from the North Slope foreland basin, Alaska: Basin Research, v. 11, p. 191-204.

O’Sullivan, P.B., Green, P.F., Bergman, S.C., Decker, J., Duddy, I.R., Gleadow, A.J.W., and Turner, D.L., 1993, Multiple phases of Tertiary uplift and erosion in the Arctic National Wildlife Refuge, Alaska, revealed by apatite fission track analysis: American Association of Petroleum Geologists Bulletin, v. 77, p. 359-385.

Parrish, J.T., Droser, M.L., and Bottjer, D.J., 2001a, A Triassic upwelling zone-The Shublik Formation, Arctic Alaska: Journal of Sedimentary Research, v. 71, p. 272-285.

Parrish, J.T., Whalen, M.T., and Hulm, E.J., 2001b, Shublik Formation lithofacies, environments, and sequence stratigraphy, Arctic Alaska, U.S.A., in Houseknecht, D.W., ed., NPRA Core Workshop-Petroleum Plays and Systems in the National Petroleum Reserve-Alaska: Society for Sedimentary Geology (SEPM) Core Workshop 21, p.89-110.

Peters, K.E., Magoon, L.B., Bird, K.J., Valin, Z.C., and Keller, M.A., 2006, North Slope Alaska-Source-rock distribution, richness, thermal maturity and petroleum charge: American Association of Petroleum Geologists Bulletin, v. 90, no. 2, p. 261-292.

Peters, K.E., Ramos, L.S., Zumberge, J.E., Valin, Z.C., and Bird, K.J., 2008, De-convoluting mixed crude oil in Prudhoe Bay field, North Slope, Alaska: Organic Geochemistry, v. 39, p. 623-645. 
Potter, C.J., Grow, J.A., Perry, W.J., Moore, T.E., O’Sullivan, P.B., Phillips, J.D., and Saltus, R.W., 2004, Tertiary thrust systems and fluid flow beneath the Beaufort coastal plain (1002 area), Arctic National Wildlife Refuge, Alaska, U.S.A., in Swennen, R., Roure, F., and Granath, J.W., eds., Deformation, fluid flow, and reservoir appraisal in foreland fold and thrust belts: American Association of Petroleum Geologists Hedberg Series, no. 1, p. 187-214.

Saltus, R.W., Potter, C.J., and Phillips, J.D., 2006, Crustal insights from gravity and aeromagnetic analysis - Central North Slope, Alaska: American Association of Petroleum Geologists Bulletin, v. 90, no.10, p.1495-1517.

Schenk, C.J., 2011a, Geology and petroleum potential of the Timan-Pechora Basin province, Russia, in Spencer, A.M., Embry, A.F., Gautier, D.L., Stoupakova,A.V., and Sørensen, K., eds., Arctic petroleum geology: Geological Society of London Memoir 35, p.283-294.

Schenk, C.J., 2011b, Geology and petroleum potential of the West Greenland-East Canada province, in Spencer, A.M., Embry, A.F., Gautier, D.L., Stoupakova, A.V., and Sørensen, K., eds., Arctic petroleum geology: Geological Society of London Memoir 35, p.627-645.

Seifert, W.K., Moldowan, J.M., and Jones, R.W., 1980, Application of biological marker chemistry to petroleum exploration: Proceedings of the 10th World Petroleum Congress, Bucharest, p. 425-440.

Shanmugam, G., and Higgins, J.B., 1988, Porosity enhancement from chert dissolution beneath Neocomian unconformity - Ivishak Formation, North Slope, Alaska: American Association of Petroleum Geologists Bulletin, v. 72, no. 5, p.523-535.

Sherwood, K.W., Craig, J.D., Lothamer, R.T., Johnson, P.P., and Zerwick, S.A., 1998, Chukchi shelf assessment province, in Sherwood, K.W., ed., Undiscovered oil and gas resources, Alaska Federal offshore: Minerals Management Service, OCS Monograph MMS 98-0054, p. 115-196.
Sherwood, K.W., Johnson, P.P., Craig, J.D., Zerwick, S.A., Lothamer, R.T., Thurston, D.K., and Hurlbert, S.B., 2002, Structure and stratigraphy of the Hanna trough, U.S. Chukchi shelf, Alaska, in Miller, E.L., Grantz, A., and Klemperer, S.L., eds., Tectonic evolution of the Bering shelf-Chukchi Sea-Arctic margin and adjacent landmasses: Geological Society of America Special Paper 360, p. 39-66.

Sørensen, K., Gautier, D., Pitman, J., Jackson, H.R., and DahlJensen, T., 2011, Geology and petroleum potential of the Lincoln Sea Basin, offshore north Greenland, in Spencer, A.M., Embry, A.F., Gautier, D.L., Stoupakova, A.V., and Sørensen, K., eds., Arctic petroleum geology: Geological Society of London Memoir 35, p.673-684.

Threlkeld, C.N., Obuch, R.C., and Gunther, G.L., 2000, Organic geochemistry data of Alaska: U.S. Geological Survey Digital Data Series DDS-59, accessed December 5, 2011, at http://pubs.usgs.gov/dds/dds-059/.

Thurston, D.K., and Theiss, L.A., 1987, Geologic report for the Chukchi Sea planning area, Alaska; regional geology, petroleum geology, and environmental geology: Anchorage, Alaska, Minerals Management Service OCS Report MMS 87-0046, 193 p.

Wallace, W.K., and Hanks, C.L., 1990, Structural provinces of the northeastern Brooks Range, Arctic National Wildlife Refuge, Alaska: American Association of Petroleum Geologists Bulletin, v. 74, p.1100-1118.

Werner, M.R., 1987, West Sak and Ugnu sands-Lowgravity oil zones of the Kuparuk River area, Alaskan North Slope, in Tailleur, I., and Weimer, P., eds., Alaskan North Slope geology: Pacific Section Society of Economic Paleontologists and Mineralogists (SEPM) and Alaska Geological Society, v. 1, p. 109-118.

Wicks, J.L., Buckingham, M.L., and Dupree, J.H., 1991, Endicott field-U.S.A., North Slope basin, Alaska, in Foster, N.H., and Beaumont, E.A., eds., Structural traps V: American Association of Petroleum Geologists Treatise of Petroleum Geology, Atlas of Oil and Gas Fields, p. 1-25. 


\section{Appendixes}

Appendixes are available only online, and may be accessed at https://doi.org/10.3133/pp1824E

Appendix 1. Input data for the Artic Alaska Platform Assessment Unit

Appendix 2. Input data for the Artic Alaska Fold-and-Thrust Belt Assessment Unit 
